A NÁ L I S E 


\section{Alvorecer de uma nova ciência: a medicina tropicalista baiana}

\author{
The dawning \\ of a new science: \\ Babian Tropicalist \\ Medicine
}

\section{Pedro Motta de Barros}

Centro de História da Ciência e da Tecnologia (CHC), Universidade de São Paulo (USP) Rua Girassol, 1585 - ap. 122, Vila Madalena, São Paulo, SP 05433-002, telefax: 815-5509
BARROS, P. M. de: 'Alvorecer de uma nova ciência: a medicina tropicalista baiana'. História, Ciências, Sauide-Manguinbos, IV(3): 411-459 nov.1997-fev. 1998.

No século XIX, o saber e o ensino médico e a assistência clínica, de caráter especulativo e elitista, entram em choque, no Brasil, com novas teorias da doença e do cuidado médico baseadas na parasitologia, bacteriologia e anatomopatologia e numa clínica experimental orientada para enfermidades tropicais dos pobres. O novo referencial teórico e social, que influi na política pública de saúde, entra em decadência quando é apropriado pela ideologia da inferioridade racial e cultural da população de origem africana. Duas novas disciplinas - antropologia física criminal e medicina legal - geram conhecimentos inéditos nos meios intelectuais e, ao mesmo tempo, são funcionais à ordem dominante, dando curso forçado a princípios e dispositivos de que a mesma elite usa para se perpetuar no poder. Essa construção híbrida é o legado de barbárie à civilizaçâo atual.

PALAVRAS-CHAVE: mudanças na cultura médica, história da medicina, história das ciências no Brasil

BARROS, P. M. de: 'The dawning of a new science: Bahian tropicalist medicine'. História, Ciências, Saíde-Manguinhos, IV(3): 411-459 nov.1997-feb. 1998.

Medicine in 19th-century Brazil was a scientific field where traditional knowledge, academic teaching, and clinical care found themselves clashing with new theories of illness and medical care underpinned by pioneer disciplines like parasitology, bacteriology, and anatomopatbology and an experimental clinical practice focused on tropical diseases which afflict the poor. This new set of theoretical and social references which affected public bealth-care policy saw its decadence when it was appropriated by an ideology that angued that the Afro-Brazilian population was racially and culturally inferior. Two new disciplines criminal physical anthropology and legal medicine - contributed to the development of specialized knowledge within intellectual circles. At the same time, they were placed at the service of the ruling order, reinforcing principles and devices that the elite utilized to keep itself in power. This hybrid structure constitutes the legacy of barbarianism which is sundering today's civilization.

KEYWORDS: changes in medical culture, bistory of medicine, bistory of sciences in Brazil 


\section{Introdução}

E ste trabalho tem por objetivo situar o processo de constituição da medicina no Brasil enquanto saber e prática dotados de legitimidade científica moderna. Meu interesse é caracterizar o papel que desempenhou o agente de saúde, não apenas como expressão de uma determinada realidade social, em diferentes momentos históricos, mas também como elemento de modernização de uma sociedade dominada por modos de produção, estruturas sociais e ambientes culturais muitas vezes avessos ao florescimento de padrões modernos na formação do saber sanitário e na assistência à saúde. Serão apontadas as condiçôes que cercaram o exercício das práticas sanitárias nos primeiros séculos do povoamento e nos periodos que se seguiram, até final do século XIX e início do século XX. Se a atenção à saúde foi marcacla durante a maior parte destes quatro séculos por saberes e práticas rudimentares, as fases mais recentes serão focalizadas com uma análise que visa demonstrar que a modernização foi um processo demorado e acidentado, nem sempre ininterrupto e irreversível, e amiúde marcado por conseqüências não necessariamente benéficas para o homem. Minhá hipótese é que a primeira tentativa de ruptura com este quadro pré-moderno só vem a ocorrer na segunda metade do século XIX, o que coincide com o caráter tardio e vacilante da instauração do sistema industrial capitalista, na forma que só viria a se consoliciar a partir da década de 1930. Investigando os trabalhos pioneiros de um grupo de médicos nacionais e estrangeiros radicados na Bahia que fundaram, fora do circuito acadêmico e da burocracia estatal, a Escola Tropicalista Baiana, e difundiram suas idéias e práticas por interméclio da Gazeta Médica da Babia, em cujas páginas se encontra a primeira manifestação, em nossa história, de um pensamento médico cuja legitimidade científica e visão social podem ser consideradas dignas de nota. Foi uma experiência, todavia, que não durou mais de quatro décadas. Evoluiu muito lentamente e atingiu poucas regiões fora de seu berço, até desaparecer, sem que viesse a fazer da medicina uma realidade capaz de transformar o quadro sanitário nacional de formá abrangente e profunda. Um novo paradigma só viria a se consubstanciar em período posterior, com a teoria especulativa racista, a antropologia criminal e a medicina legal de Nina Rodrigues. Este novo paradigma apresentou problemas teóricos e práticos de ordem similar, mas diferentes, à do estatuto científico - parasitologia, bacteriologia, anatomopatologia e fisiologia clínica experimental - de Wücherer e seus colegas de primeira hora. Similar porque envolveram questões atinentes aos seguintes pontos: representações parecidas do quadro nosológico da população pobre do país, e maneiras semelhantes de formular algumas aproximações 
epistemológicas e de configurar algumas análises do processo de produção de conhecimentos, da prática científica (principalmente nos aparelhos institucionais e acadêmicos existentes), da formação teórico-ideológica (notadamente em suas articulaçôes com os meios de produção dos discursos científicos), e dos conceitos e noções referentes ao saber médico da época. E ao mesmo tempo diferentes, porquanto as formas peculiares sob as quais se organizara o saber, o ensino e o ofício médicos, na situação social e no contexto histórico concreto do Brasil da segundá metade do século XIX, assumira um significado que impõe o controle repressivo da força de trabalho, para cuja consecução se agenciara as seguintes mediações: submissão a idéias de inferioridade racial de negros e mulatos, correlativas às de superioridade congênita de brancos e de confiáveis mestiços de 'alto nível'; reverência a princípios alienígenas de prestígio para camuflar sua incongruência com a defasagem interna cle instituições e valores anacrônicos; cooptação de intelectuais sujeitos à heteronomia ética para prestarem serviço ao poder oligárquico; separação forçada entre a comunidade científica e as instâncias autônomas da sociedade civil; e neutralização dos diletantes que aspiram a alguma condição de pesquisa livre e original.

\section{O quadro externo: ciências em movimento}

Seria impróprio dizer que as práticas sanitárias trazidas pelos portugueses eram arcaicas. Arcaicos foram os métodos dos antigos egípcios, gregos, romanos, indus, chineses e árabes. Muito antes de nossa era, havia entre esses povos autores de práticas médicas dotadas de certa racionalidade que contrariavam as práticas mágicas e religiosas que reinavam em suas antigas culturas. É preciso sublinhar que a medicina hipocrática baseia-se na concepção de um sistema de causas e efeitos mecânicos que põem o problema da doença numa linguagem e num plano de inteligibilidade isto é, em termos teóricos - que são em tese os mesmos do pensamento científico. Suas hipóteses e seus conceitos apóiamse num modo de verificação de sintomas que chama a atenção pela sagacidade e segurança do golpe de vista clínico do médico, e, em particular, pela dimensão humana com que seus pacientes eram objeto de atenção. Seus relatos das histórias dos doentes ainda hoje podem ser lidos com emoção (Starobinski, 1967, pp. 19-31). A ciência médica grega atinge seu momento culminante na escola de Alexandria, em especial a partir do século III a. C. A técnica anatômica enriquece-se de maneira considerável. Depois de Galeno, o último dos grandes médicos da Antiguidade, o esforço inventivo da ciência médica estanca por perto de mil anos. Enquanto o Ocidente cristão regressa ao nível das práticas mágico- 
religiosas, os intelectuais árabes (Nasr, 1979) assimilam desde o século VII a herança grega, que se completa com observações clínicas (muitas vezes extrapoladas com especulações astrológicas e mágicas) e se transmite em tratados enciclopédicos entre cujos autores se destacam Rhazés, Abulcasis, Ibn an Nafis, Avicena e o grande filósofo Averróis. Este saber médico árabe exerce profunda influência sobre os homens do Renascimento e perpetua-se ainda em nossos dias, às vezes sob a forma de vulgarização esotérica. $\mathrm{Na}$ Idade Média, a influência da Igreja católica desvia os médicos da prática cirúrgica. Ecclesia abborret a sanguine: a Igreja tem horror ao sangue. Por isso, as intervenções cirúrgicas tornam-se apanágio dos leigos ou barbeiros: incisões de abcessos, trepanações, amputações são confiadas a uma corporação artesanal cuja arte 'mecânica' é tida como desprezível por aqueles que estudaram as 'artes liberais'. A estagnação da ciência médica na Idade Média não é conseqüência apenas do esquecimento dos métodos da investigação científica; é preciso levar em conta uma escolha de valores. À luz da fé cristã, é preciso preocupar-se menos com a vida do corpo do que com a vida da alma. $O$ desenvolvimento dos hospícios e hospitais tem como principal razão a aplicação da virtude da caridade, mais do que a intenção de aplicar um tratamento adequado às diversas doenças.

Mas existe desde a Idade Média uma teoria da revelação natural que afirma que, ao lado dos livros santos, Deus nos deu o livro da Natureza, onde se podem decifrar todas as verdades que Ele nos destina. Devemos aprender a lê-lo por nós mesmos, e não simplesmente aceitar o que os outros intérpretes nos transmitem por meio da leitura de livros autorizados pelos teólogos, como prevalecia até o século XIII. Era chegado o momento de mudar esta ordem e abandonar idéias preconcebidas. Era na anatomia, disciplina da observação metódica, que o novo espírito devia primeiro manifestar-se. Para perceber a diferença dos tempos, basta confrontar a melhor anatomia medieval, a do bolonhês Mondino de Luzzi (c. 1275-1326), com os trabalhos de Leonardo da Vinci (1452-1519). Enquanto um terrível fanatismo religioso dominava os espíritos e se estarrecia ante a coragem de Mondino, que dissecava corpos humanos para estudos de anatomia, e cuja obra pioneira, Anatomia Mundini, foi adotada pelas escolas italianas até o século XVII (Santos Filho, 1977, p. 280), a obra de da Vinci era celebrada como exemplo do novo espírito humanista que empolgava o mundo. Com base nos estudos de da Vinci, André Vesálio (1514-64) produz um livro soberbo - De bumani corporis fabrica - que opera a grande reforma da anatomia e marca o início da libertação da medicina moderna. Os conhecimentos são logo aproveitados pelos cirurgiões. Ambroise Paré (1510-90) será a mais ilustre testemunha do Renascimento 
da cirurgia. Ele reencontra o princípio hipocrático da vis medicatrix naturae, potência medicatriz da natureza - o cirurgião é antes de tudo servidor das forças naturais. Com a transição da anatomia estática para a anatomia animata, passa-se à fisiologia, momento em que se reconhece o interesse pelo movimento, que caracteriza a idade barroca (Canguilhem, 1982, pp. 165-6). Toda a obra de William Harvey (1578-1657), que demonstrou com clareza a circulação do sangue, é uma interpretação dos fenômenos dinâmicos do organismo. Sua teoria é uma ampliação sistemática de uma hipótese aproximada e duas descobertas empíricas (Starobinski, 1967). A hipótese é do médico e teólogo espanhol Miguel de Servet (1509-53), com base em argumentos de ordem religiosa, razão pela qual foi queimado vivo em Genebra (Santos Filho, 1977, p. 284). As descobertas empíricas pioneiras foram feitas pelo cirurgião árabe Ibn an Nafis (?-1288), que descobriu a pequena circulação entre o coração e o pulmão (Nasr, 1979, p. 233), e pelo médico cremonense Mateo Realdo Colombo (151659), que descobriu o clitóris (Andahazi, 1997). De maneira geral, durante os séculos XVII e XVIII, a renovação dos conhecimentos médicos nos países adiantados da Europa não sofreu interrupção.

\section{O quadro interno: minoridade intelectual e práticas rudimentares}

Em contraste com essa realidade, a situação no Brasil refletia a de Portugal, onde o atraso geral não podia deixar de atingir também a medicina. Mesmo comparada às condições das culturas arcaicas, a medicina introduzida no Brasil, descle a descoberta até a segunda metade do século XIX, era rudimentar no tocante às práticas clínicas e cirúrgicas. Devido às grandes lacunas de conhecimentos acerca das doutrinas da Antiguidade clássica, da Idade Média árabe e do empirismo baconiano, assim como dos movimentos culturais que empolgaram a Europa entre o Renascimento e o Iluminismo, e que iriam desembocar na grande revolução da medicina do século XIX, "a mais notável que a medicina experimentou nos tempos modernos" (Foucault, 1972, p. 198), a cultura médica no Brasil foi entorpecida por uma base intelectual tosca em termos de assimilação da literatura especializada e de reflexão teórica autônoma, assim como cheia de preconceitos nos campos da observação clínica, dos procedimentos terapêuticos e, em, particular da experimentação anatômica. Não devemos esquecer que, enquanto na maior parte da Europa, do século XII em diante, o progresso dos conhecimentos laicos foi intensamente animado pela proliferação das cidacles, pela efervescência intelectual (Le Goff, 1957) e pelo florescimento das universidades (Charle e Verger, 1996), a vida social e cultural 
em Portugal fazia dele um país anacrônico (Janotti, 1992) em relação ao renascimento europeu (Sevcenko, 1994). Pior do que isso, passou a sofrer, a partir do século XVI, um retrocesso tamanho que incluiu até a restauração da Inquisição. Do ponto de vista de uma certa interpretação histórica, teriam sido mínimas as manifestações de não-conformismo a tais violências, visto que teria existido um clima cultural mais geral que impunha critérios adaptativos extremamente rígidos à transferência de problemas de um contexto histórico desapareciclo para um contexto atual. O argumento central é que a atmosfera mental da época, na península ibérica, inclinava-se antes de tudo para a imitação servil de valores antigos, muitos de ordem transmundana, que já haviam passado pelo crivo seletivo da consciência crítica e humanista das nações mais adiantadas da Europa, que desde o século XIII davam passos firmes rumo à maturidade (Le Goff, 1957, pp. 73-133). Isso pode ser atribuído em grande parte ao efeito avassalador da Inquisição ibérica, utilizada, como em nenhum outro lugar do mundo, como instrumento clestinado a cumprir o duplo objetivo de manter no poder político uma nobreza retrógrada e clefender a cultura obscurantista de uma casta sacerdotal empenhada em controlar nos mínimos detalhes a vida cotidiana do povo (Saraiva, 1994). Os fatos históricos subseqüentes iriam mostrar que essa anomalia afetaria também a colônia ultramarina, embora ela puclesse, paradoxalmente, se beneficiar com o êxodo das melhores vítimas do obscurantismo metropolitano, como aliás aconteceria com as colônias do império anglo-saxão. Assim, enxotados pelo ódio fanático e pela cobiça de d. João III, muitos intelectuais, e em particular judeus expropriados de seus bens, buscaram refúgio no Brasil. Um deles, o médico Jorge Valadares, chegou a Salvador em 1549. Foi o primeiro licenciado ou físico a exercer a profissão no Brasil (Santos Filho, 1977, p. 307). Fazia parte de uma minoria de formados nas escolas européias que praticavam a clínica, a medicina interna. Veremos adiante que seriam os egressos desses centros universitários avançados que, três séculos mais tarde, introduziriam os germes da revolução cientifica na medicina brasileira.

Mas os primeiros imigrantes eram de pouco saber, pois os mais preparados convertiam-se por conveniência em cristãosnovos e ficavam na metrópole, não se submetendo aos dissabores da vida da colônia. Não obstante, conseguiam entreter aqui relações privilegiadas com as classes dominantes porque, na hierarquia valorativa da época, transmitiam o prestígio de exercer uma atividade que concerne ao interior do corpo humano, desconheciclo e inacessivel aos sentidos, envolvendo um nível mais elevado de raciocínio abstrato.

Em inferioridade na hierarquia dos valores espirituais estavam os cirurgiões-barbeiros, assim considerados por exercerem atividades 
que, segundo o estatuto cultural da época, não exigiam atributos intelectuais, mas apenas ações concretas, visíveis e palpáveis. Já vimos que a anatomia era uma ciência malvista por teólogos e acadêmicos conservadores. O estudo de anatomia no Brasil praticamente não existiu até o século XIX, apesar de as pesquisas nesta área já terem um desenvolvimento considerável na Europa desde o século XVI. Isso porque o estudo anatômico com cadáveres humanos, contrariamente ao que acontecia na Europa moderna (Foucault, 1972, pp. 125-7), era proibido entre nós pelo Santo Ofício, bem como as necrópsias. De tal modo que os atestados de óbito eram bastante precários, dificilmente identificando a real causa mortis. Foi Willem Pies (1611-78), médico holandês que clinicou em Pernambuco no século XVII, quem fez as primeiras necrópsias no país, pois estava a salvo das ações do tribunal do Santo Ofício (Pires, 1989, p. 46). Vale ressaltar que é também de autoria dele - considerado o mais atilado observador do campo médico nacional - o primeiro tratado brasileiro de patologia e terapêutica: De Medicina Brasiliensi (1648). Com ele se inauguram os registros sistemáticos sobre as doenças endêmicas da terra e a medicina ameríndia, principalmente as propriedades curativas da ipecacuanha e do jaborandi. Mas é um marco inicial e circunscrito ao território batavo, sem qualquer repercussão no Brasil português, desconhecido que ficou dos profissionais luso-brasileiros.

Lidando exclusivamente com o lado externo do corpo humano, os cirurgiões eram treinados para atos específicos de base operacional e manual, estabelecendo com os físicos a divisão entre trabalho intelectual e manual, sendo este identificado com o braço servil. Além dos atos cirúrgicos comuns na época, ainda sangravam, sarjavam, aplicavam ventosas e sanguessugas, extraíam dentes, barbeavam e cortavam cabelo (Santos Filho, 1977, pp. 39, 65). Ao lado dos cirurgiões, também exerciam ações de saúde os boticários e seus aprendizes, os aprendizes de barbeiros e de cirurgiãobarbeiro, os anatomistas, os algebristas ou endireitas (cuidavam de fraturas ósseas), curandeiros, entendidos, curiosos e parteiras. No conjunto, suplantavam em muito o número de físicos.

Até o século XVIII, físicos e cirurgiões eram em geral de condição social humilde e tratados como serviçais dos burgueses, donos de terras, nobres e clérigos. O nível cultural da maioria era dos mais baixos. Ainda no século XVIII, denotavam insuficiente formação escolar haurida em Coimbra e Salamanca, e persistiam alheios aos avanços alcançados pela medicina, sendo raros os dotados de cultura humanística. A ignorância revelada por muitos deles mereceu sarcásticos comentários de seus coevos e críticas desabusadas de escritores notáveis, como Antônio José da Silva, o Judeu, e Nuno Marques Pereira. 
Desde 1673, Anton Leeuwnhock havia inventado o microscópio. Edward Jenner decobriu a vacina antivariólica em 1797 (Coe, 1973, pp. 212-3). Mesmo assim, o Brasil continuou sem desenvolver pesquisas e sem intercambiar conhecimentos nativos sobre o efeito terapêutico das ervas medicinais e dos procedimentos de cura com as instituições científicas internacionais. Explica-se: o governo imperial proibia a imprensa e a liberdade de expressão do pensamento ilustrado impondo férrea censura à edição e importação de livros subversivos, controlando as bibliotecas dos intelectuais dissidentes, sob o regime colonial por intermédio do Santo Ofício, e, mesmo depois da transferência da família real, com a instalação da Mesa do Desembargo do Paço (Frieiro, 1981). A introdução da variolização no Rio de Janeiro pelo cirurgião-mor Francisco Mendes Ribeiro, em 1798, foi uma tentativa isolada de caráter voluntarista, para resolver problemas localizados na tropa de que o mesmo era comandante e em alguns portos, tendo sido escravos africanos suas primeiras cobaias. Em conseqüência, portanto, da falta de uma orientação sistemática e abrangente de pesquisa científica e saúde coletiva, não foi possível debelar os violentos surtos da doença, que se repetiram até o início do século XX (Pires, 1989, pp. 49, 96). Convém assinalar que, nessa época, não houve vacinação geral com a linfa vacínica produzida em laboratório pelo médico inglês Edward Jenner no úbere de vacas, mas a variolização, ou mera inoculação do pus da varíola de indivíduo a indivíduo, sem observância dos critérios epidemiológicos de controle experimental reconhecidos pelo estatuto epistemológico da época (Santos Filho, 1977, p. 270). Passado quase meio século, o Brasil continuava praticando o método oriental de variolização observado em Constantinopla em meados do século XVIII por lady Mary Wortley Montagu (1689-1762) (Starobinski, 1967, p. 57). Como tampouco houve destinação regular de recursos orçamentários significativos para a atividade, explica-se seu abandono prematuro. Apesar de o meio revelar alguma potencialidade endógena para dar resposta às necessidades reais da maioria da sociedade, os movimentos de assimilação das inovações estrangeiras eram amiúde esterilizados pela ignorância das elites dominantes e pela estreiteza de vistas dos governos, cujo imediatismo limitava as despesas de saúde à vigilância dos portos, para garantir o comércio com o exterior, e ao ataque afoito às epidemias de febre amarela e varíola para não assustar imigrantes estrangeiros e membros da corte aqui instalada. "A preocupação não é com a promoção da saúcle da população" (Pires, 1989, pp. 65-72).

Essa impermeabilidade aos progressos da medicina iria acarretar conseqüências fatais no próprio seio da família real. Com sua visão de estadista, o marquês de Pombal (1699-1782) planejou uma estratégia palaciana (que envolvia a aplicação da lei sálica) 
para que o príncipe d. José fosse escolhido sucessor imediato do rei d. José I, fiador das reformas burguesas em Portugal e colônias ultramarinas. Seu plano incluiu a determinação ao frei Cenáculo, um oratoriano iluminista, adversário dos jesuítas, para que educasse cuidadosamente o príncipe com aquele fim. Tencionava-se, dessa forma, evitar que o trono de Portugal fosse ocupado por um nobre reacionário. Por ironia da história, a rainha d. Maria, a Louca, inimiga de Pombal e responsável pela ordem de reprimir os inconfidentes das Minas Gerais e de esquartejar o alferes Joaquim José da Silva Xavier, o Tiradentes, opôs-se à aplicação da vacina recém-descoberta no Oriente e experimentada com sucesso por médicos francesas e ingleses. Sem imunização tempestiva, o príncipe d. José, filho da rainha, sucumbiu à varíola em 1788, arruinando o plano do marquês de Pombal, cuja posição já tinha se tornado insustentável com a morte do rei em 1777 (Maxwell, 1996, pp. 160-1).

Só de meados do século XVIII para frente é que os físicos e cirurgiões passam a usufruir de melhor consideração social, e começam a trabalhar doutores formados nas faculdades francesas e, principalmente, em Edimburgo, o mais acreditado centro científico europeu. Em 1772, as reformas pombalinas chegam à Universidade de Coimbra. Entre seus objetivos, estavam o de "atualizar totalmente a Faculdade de Medicina, fazendo voltar o estudo de anatomia por intermédio da dissecação de cadáveres; o estudo de higiene, 'porque é mais fácil conservar a saúde do que recuperá-la uma vez perdida'; adotar as descobertas de Harvey relacionadas com a circulação do sangue, as teorias de Albinus em anatomia, as de Boerhaave em patologia e as de Van Swieten em farmacologia" (idem, ibidem, pp. 110-1). Lançam-se as bases da influência que o médico irá exercer na sociedade brasileira, no século XIX (Santos Filho, 1977, pp. 303-26). Viriam de universidades européias os profissionais que trouxeram as sementes de uma nova ciência médica no Brasil. Isso pode ser atribuído à grande revolução cultural introduzida pelo marquês de Pombal, durante seu governo (1750-77). Suas medidas, no sentido de substituir no poder político a nobreza antiquada por uma burguesia mercantil progressista, foram de tal forma arrojadas que chegaram a atingir o coração do obscurantismo religioso (Saraiva, 1994, pp. 202-10). O fato punha em xeque aquela hermenêutica determinista vulgar, aludida há pouco, que subestima a plasticidade do ambiente cultural e petrifica suas propriedades virtuais de transformação diante da força inexorável da ideologia dominante. Este fenômeno notável - o qual, conforme Saraiva (op. cit.), parecia demonstrar que o problema da incredulidade não pode ser reduzido inteiramente aos termos com que se procurou explicar a inevitabilidade da fé religiosa de Rabelais no século XVI (Febvre, 
1968) - acabou por ser em parte revertido com a queda de Pombal, no final do século XVIII, em virtude do fato de que ele não formou uma escola de pensamento que desse continuidade a seus projetos modernizadores. Sem ignorar a realidade mais profunda, subjacente à própria orientação de conjunto do despotismo esclarecido: o regime de Pombal não foi capaz de resolver o grande conflito entre tradição e inovação. Reforçadas pela ideologia racionalista, que forneceu a desculpa conveniente para o despotismo pombalino, as imagens contraditórias do Portugal do século XVIII, dessa perspectiva, estão em boa parte anuladas. Em um sentido real, ambas as imagens são precisas, porque o outro lado da moeda do atraso pode ser a ordem, e o do progresso pode ser a tirania. Em nenhum dos casos havia muito espaço para a liberdade individual. Esse espaço havia sido decididamente ocupado com antecipação pelo absolutismo estatizante (Maxwell, 1996, pp. 159-77). Do outro lado do Atlântico, este legado não seria menos avassalador.

\section{Idéias especulativas}

$O$ ensino médico teve problemas de institucionalização e modernização até o século XIX. Convém reiterar que, antes da criação das primeiras faculdades de medicina, o atendimento médico no Brasil era feito exclusivamente por curandeiros herbalistas, seguidores dos conhecimentos empíricos dos indígenas, africanos e jesuítas, ou por práticos, geralmente analfabetos e de camadas sociais humildes, sem nenhum prestígio profissional. Com a criação dos cursos médico-cirúrgicos, em 1808, iniciou-se um tortuoso processo de reconhecimento da profissão de médico como atividade que implicava conhecimentos diferentes dos adquiridos de maneira artesanal, característicos dos práticos. Médicos de prestígio fundaram, em 1829, a Sociedade de Medicina do Rio de Janeiro, cuja primeira atribuição foi estudar projetos de reforma do ensino médico, de maneira a promover uma nova organização que marcasse a passagem de uma medicina assumida como sintomatista e empírica a uma que se propunha a ter bases mais racionais. A principal crítica que se fazia às escolas médicas era que de seus currículos não constavam as chamadas ciências acessórias - física, química, botânica -, indispensáveis para formar profissionais conscientes da complexidade do conhecimento científico e do dever de conservar a saúde e prestar assistência ao doente. Por isso, a ênfase das escolas nunca tinha deixado de ser a clínica, vale dizer, voltada para a prática diretamente curativa, baseada apenas nas impressões práticas colhidas pelo clínico na cabeceira do enfermo, e inspirada em fantasias causais, tais como a influência de miasmas (efeitos da putrefação de matérias orgânicas) 
e do meio geográfico, e conjecturas extravagantes eivadas de falsas interpretações anatômicas, fisiológicas, humorais, climáticas, alimentares e até morais. Essas doutrinas decorriam principalmente da influência dominante de ilusões morais e fantasmas religiosos, oriundos quer das culturas indígenas e africanas, quer do catolicismo ultramontano trazido pelos jesuítas. Se bem que não se pode deixar de reconhecer que havia um grande potencial de conhecimento verdadeiro a ser desenvolvido a partir das substâncias naturais e dos procedimentos terapêuticos adotados por indígenas, africanos e jesuítas.

O que foi dito a respeito da ignorância das elites e da incúria dos governos pode ser ilustrado pelo testemunho de Auguste de Saint-Hilaire (1974), quando descreve o tipo de formação cultural dos jovens filhos da elite econômica que eram enviados para estudar em Paris e trocavam os estudos pela frivolidade. Sequer tinham estofo espiritual para reviver a "vadiagem escolar" com que os goliardos do século XII escandalizavam os espíritos tradicionais e as estruturas sociais estabelecidas, quando catavam, de cidade em cidade, os ensinamentos dados pelos mestres que lhes animassem o espírito crítico e lhes expandissem o horizonte intelectual (Le Goff, 1957, pp. 9-69). Vagabundos primários, nada faziam senão desperdiçar energias e o dinheiro do povo e dificultar ainda mais a criação de uma verdadeira comunidade intelectual dedicada ao esforço de colocar o país em sintonia com os novos ares do mundo (Saint-Hilaire, 1974, p. 217).

Não era fortuito, portanto, que pesasse sobre o sistema de concessão de título de médico ou cirurgião, adotado pelo governo imperial, principalmente a partir de 1809 , a suspeita de fraudes, pois a forma de nomear a banca examinadora dos candidatos permitia titulação por critérios econômicos, mediante pagamento de propinas (Lobo, 1964, p. 18). Fenômeno enfrentado também pela medicina européia desde o final do século XVIII (Gilibert, 1772, pp. 58-118; Thiery, 1789), a concussão era um aspecto de uma estrutura complexa que exigia reformas profundas no ensino, na organização da pesquisa científica, no exercício da profissão e na assistência à população. Essas reformas (chamadas a si pela Revolução Francesa) implicavam a condenação de um liberalismo político, econômico e científico que foi obstáculo à organização da medicina clínica moderna. Era preciso ultrapassá-lo para abrir o saber à atualização teórico-experimental, eliminar o esoterismo do ensino canônico, tirar do treinamento prático a máscara que ocultava a estrutura tecnológica de uma medicina aparentada com o darwinismo social, abolir os privilégios sociais e tornar eficaz a vigilância da saúde da nação (Foucault, 1972, pp. 37-52). Nosso século XVIII já tinha ficado para trás, e nossas classes dominantes nem sonhavam em incluir esses temas em sua agenda política. 
Topando com essa elite apoucada de descortino civilizatório, os poucos espíritos comprometidos com o desenvolvimento da ciência no país viam se frustrar seus sonhos e gorar seus projetos. Sufocadas por um sistema de valores que descorçoava o pensamento original, relegadas a um ambiente cultural sem dinamismo próprio, passando ao largo de uma população de escravos, pobres e analfabetos, corpo estranho em um sistema econômico primário e dependente das correntes de comércio internacionais, e incompatíveis com um aparelho estatal que simplesmente bloqueava a difusão das idéias iluministas e se eximia de consignar verbas orçamentárias para o progresso das ciências, as novas idéias científicas não prosperavam. As receitas fiscais destinavam-se, em sua quase totalidade, ao interesse obsessivo de montar e conservar o poder de uma estrutura administrativa patrimonial e militarizada, no único propósito de fortalecer uma máquina política que se sustentava em prebendas, favores e liturgias. Essas regalias eram a moeda de troca que os cortesãos do imperador, instalados no ápice da pirâmide do poder, traficavam com seus prepostos diletantes, pertencentes às oligarquias agrárias que defendiam seus domínios entrincheiradas nos municípios (Uricoechea, 1978). Decorrência desse dispositivo absolutista, destituído de requisitos da burocracia profissional moderna, a manipulação dos recursos estatais dava-se em proveito exclusivo da clientela rural. Não é de estranhar, portanto, que ao longo de todo o período imperial tenham se verificado esvaziamento das funções públicas típicas voltadas para o bem-estar do povo e destinação de despesas orçamentárias insignificantes para rubricas de desenvolvimento da medicina e programas de saúde pública (Carvalho, 1988, pp. 34-49).

Pode-se imaginar facilmente o impacto dessa incúria administrativa no campo da formação da comunidade médica. Fazendo contraponto com uma máquina política cujas vigas-mestras eram constituídas por funcionários diletantes, nada mais normal do que uma ciência cultivada por diletantes. Em todo caso, apesar do retrocesso que se seguiu à Viradeira (o reinado de d. Maria I, a Louca), as idéias renovadoras do período pombalino haviam trazido alguma oxigenação ao ambiente intelectual da colônia. Mas naturalmente sem o significado nem a dimensão com que as transformações se sucediam nos países avançados da Europa, em especial no campo da medicina.

Não pretendo discorrer em minúcia sobre os principais nomes que trouxeram contribuições importantes ao conjunto da medicina. Vários autores conhecidos podem oferecer panorama detalhado sobre o tema. Para os fins deste artigo, interessa ressaltar o papel desempenhado pelos pesquisadores de anatomia e anatomopatologia, e suas relações com a fisiologia e a clínica. Dentre eles, o mais destacado é sem dúvida François-Xavier Bichat (1771-1802), que 
entrosou a anatomia com a fisiologia e realizou investigações antomopatológicas de conseqüências revolucionárias no conhecimento da fisiologia e dos métodos clínico-terapêuticos. Publicou várias obras de grande repercussão, como Recherches physiologiques sur la vie et la mort (1800).

Claude Bernard (1813-84) desenvolveu o método experimental e aplicou a vivissecção. Entre suas descobertas estão a função glicogênica do fígado, o calor animal, a fisiologia da nutrição e outras que expôs em tratados importantes como Leçons de physiologie expérimentale appliquée à la médicine (1855) (Santos Filho, 1991, pp. 30-1). Teve papel central na fundamentação científica das disciplinas clínicas e no eixo epistemológico básico do movimento médico reformista do Rio de Janeiro na segunda metade do século XTX (Edler, 1992, pp. 136-56, 228).

O quadro geral é de acentuado progresso nessas especialidades, porquanto todas elas eram impregnadas por um clima de pensamento ancorado no mundo real e na experiência humana, fontes primordiais de ousadas investigações, concepções originais e idéias singulares. Isso não impedia que surgissem também doutrinas e sistemas especulativos que procuravam explicar os fenômenos patológicos e fisiológicos, mediante a construção de aporias e bizarrias místicas. Apesar de refutados pelo estatuto epistemológico do pensamento moderno em formação, não deixaram de contribuir, na antiga tradição eleata do raciocínio por absurdo, para o desenvolvimento da patologia e da clínica (Santos Filho, 1977, pp. 286-8). Ilustração disso foi o "animismo" de Georg Ernst Stahl (1660-1734), segundo o qual a alma regula o funcionamento do organismo. Foi dele também a idéia do "flogístico" para explicar a combustão. Em registro semelhante, o "vitalismo" ou a doutrina da "força vital" teve seus principais propugnadores em Théophile Bordeu (1722-76), que achava que cada órgão possuiria sensibilidade própria, e em Paul Joseph Barthez (1734-1806), o qual, não admitindo a pluralidade de "forças vitais", propôs um único "princípio vital" como causa explicativa universal do funcionamento de todos os órgãos. Pierre Jean Georges Cabanis (1757-1808) relaciona a moral à física. Franz Joseph Gall (17581828) lança as bases da "frenologia", a teoria das localizações cerebrais, que inspirou algumas correntes racistas do biologismo do século XIX. Pelo "mecanicismo" de Friedrich Hoffmann (16601742), a matéria rege-se pelas leis da mecânica, da física e da química, extremando-se o enfoque materialista vulgar que, na época, teve papel relevante na crítica da mentalidade mística e da filosofia idealista.

Veremos como essas concepções tão contraditórias formaram o caldo de cultura em que se deu a passagem do saber especulativo para o saber científico moderno. Para isso, muitas universidades 
e faculdades isoladas tiveram de ser fechadas e reformadas (Foucault, 1972, p. 48), pois eram bastiões da mentalidade conservadora. Em conflito com elas, criaram-se sociedades de medicina que lideraram importantes movimentos de índole experimental no interior dos hospitais (Foucault, 1972, pp. 26, 35, 37-52, 63-86) e que emulavam com o ensino desenvolvido nas faculdades de Montpellier e Edimburgo, e em outras da Alemanha e Itália.

Nelas doutoraram-se alguns jovens brasileiros, os quais permaneciam em Portugal ou regressavam ao Brasil (Santos Filho, 1977, p. 289-96). Distanciavam-se eles, pela prática e pelo saber, dos diplomados por Coimbra, onde os lentes não evoluíram, não assimilaram e muito menos transmitiram os conhecimentos, as teorias e as descobertas processadas além-fronteiras. Demonstravase anatomia ainda pela forma comparativa, exibindo-se os órgãos de um carneiro. Em Portugal, ainda no século XVIII, tanto na medicina como nas demais ciências, e na cultura em geral, imperavam a ignorância e a superstição (Dias, 1953, p. 122). Em decorrência da intolerância e do fanatismo, os mais ilustrados profissionais, judeus quase todos, expatriaram-se e privaram a universidade de seu saber. Dentre eles, citam-se Antônio Nunes Ribeiro Sanches (1699-1783) e Jacob de Castro Sarmento (16911762). Ambos publicaram no estrangeiro obras de valor, provavelmente lidas e aproveitadas apenas por alguns profissionais lusos. Ribeiro Sanches, considerado o pai da moderna medicina portuguesa, foi um dos primeiros a contribuir para a reforma da Universidade de Coimbra, em 1772, durante o governo do marquês de Pombal (Barros, 1997).

Um famoso parente de Ribeiro Sanches, Francisco de Melo Franco (1757-1823), foi perseguido pela Inquisição de Lisboa na segunda metade do século XVIII, acusado de receber dele literatura subversiva - ou seja, Rousseau, Voltaire, Mirabeau, Montesquieu, Beccaria - e participar de reuniôes heréticas. É autor de uma obra diversificada. Uma das mais importantes - Medicina teológica (Franco, 1994) - foi censurada pelo governo. Segundo Afonso Arinos de Melo Franco (1976, p. 111), o livro propõe a tese quase freudiana de que muitas vezes os pecados, os desvios da alma, não são mais do que doenças ou perturbações da saúde.

José Correia Picanço (1745-1824) contribuiu decisivamente para a criação do ensino médico-cirúrgico no Brasil, inicialmente ministrado de forma prática em vários hospitais. O primeiro curso formal de cirurgia foi posto a funcionar em 1803 no Hospital Militar de São Paulo. Mas foi extinto três anos depois, quando o governador, por razões administrativas, desentendeu-se com o físico-mor, moveulhe processo e prendeu-o (Santos Filho, 1977, pp. 294-6).

Nunca será demais repisar a responsabilidade do fanatismo religioso pelo atraso cultural do Brasil na época em exame. Trago 
aqui o testemunho insuspeito de Francisco Adolfo de Varnhagen, visconde de Porto Seguro, justamente festejado nos círculos conservadores por sua atuação como vassalo extremoso da corte imperial e autor de uma obra histórica notável pelo esforço de pesquisa documental e pelo intuito assumidamente apologético de justificar a concentração do poder da nobreza, do alto clero e das classes proprietárias que dominaram o Brasil até o século XIX (Odalia, 1997). Nem mesmo Varnhagen (s. d., p. 191) titubeou em associar a atuação do Santo Ofício à voracidade material da casta sacerdotal e ao propósito de embotar a capacidade intelectual do povo brasileiro. Em suas próprias palavras, as "influências perniciosas (da Inquisição), que eram quase todas", atingiram seu ponto "máximo desde o século passado (XVIII), em que as riquezas começaram a seduzir os cobiçosos fiscais do chamado Santo Oficio, deste Status in Statu, cujos ditames, superiores a toda lei, diminuíam ao rei a majestade, ao governo o poder, aos tribunais a justiça, aos prelados a autoridade eclesiástica, e aos povos a liberdade - não só de discutir, como até de pensar".

Essas condições ideológicas e institucionais estrangulavam a assimilação da medicina moderna no Brasil. Isso atingiu principalmente a clínica e a anatomia, em particular a anatomopatologia e suas articulações com a fisiologia, campos em que, nos séculos XVIII e XIX, a Europa viveu grandes progressos. Mas a comunidade médica brasileira, como extensão da tradição portuguesa, ignorou esses progressos e passou a incorporar, quando muito, o lado livresco, especulativo e preconceituoso do ensino francês. À semelhança deste, herdado do Antigo Regime, e sob a influência das filosofias de Descartes e Malebranche, a medicina francesa, antes do final do século XVIII, era marcada por um pressuposto metafísico essencial: ver é perceber o dado imediato da extensão plana mostrada pela linha reta da luz. Assim, denunciando o caráter empiricista, subjetivista, mecanicista, formalista e idealista da medicina pré-moderna, a configuração primária da doença era governada por quatro princípios (Foucault, 1972, pp. ix, 2-19).

Superficialidade. A doença é percebida fundamentalmente em um espaço de projeção sem profundidade, e, por conseguinte, sem desenvolvimento. A forma sob a qual a verdade se mostra originalmente é a superfície onde o relevo ao mesmo tempo se manifesta e se extingue - nada mais do que um retrato (Sydenham, 1784; Sauvages, 1772 , p. 88). A estrutura primeira que se concede à medicina classificatória é o espaço plano do perpétuo simultâneo, como o retrato chapado de uma mesa.

Identidade por analogia. A doença é um espaço no qual as analogias definem as essências. Os quadros se parecem, tanto quantoas essências. De uma doença a outra, a distância que as separa se 
mede pela única gradação da semelhança entre elas, sem que intervenha inclusive a separação lógico-temporal da genealogia. No espaço simultâneo no qual as formas distribuídas pelo tempo se reúnem e se superpõem, o parentesco se contrai em identidade. No mundo plano, homogêneo, não métrico, existe doença essencial onde há pletora de analogias (Cullen, 1785, p. 86).

Legalidade interna ditada pela analogia das formas. A forma da analogia revela a ordem racional das doenças. É como se a analogia valesse tanto quanto a lei que preside a produção das doenças. Quando se percebe uma semelhança, não se fixa simplesmente um sistema de sinais cômodos e relativos; começa-se, sim, a decifrar o ordenamento inteligível das doenças. Vale dizer, lê-se nos sinais a estrutura racional, discursiva e necessária da doença. O véu se levanta sobre o princípio de criação das doenças: é a ordem geral da natureza. Ou, por outra, a forma da analogia se parece consigo mesma somente à medida que esta semelhança foi dada desde o começo da construção das doenças. Como para a planta ou o animal, o jogo da doença é fundamentalmente traduzido em uma lei específica. Este modelo botânico tem dupla importância para o pensamento médico. Permite primeiro que o princípio da analogia das formas seja invertido em lei de produção das essências: da mesma maneira a atenção perceptiva do médico que, aqui e ali, encontra e aparenta sinais, se comunica de pleno direito com a ordem ontológica que organiza a partir de dentro, e antes de qualquer manifestação, o mundo da doença; o reconhecimento se abre desde a origem sobre o conhecimento, o qual inversamente encontra no reconhecimento a forma primeira e radical de conhecimento. Por outro lado, a ordem da doença não é senão um decalque do mundo da vida: as mesmas estruturas reinam cá e lá, as mesmas formas de repartição, o mesmo ordenamento. A racionalidade da vida é idêntica à racionalidade do que a ameaça. Elas não são, uma com relação à outra, como a natureza e a contranatureza; ao contrário, em uma ordem natural que lhes é comum, se encaixam e se superpõem. Na doença reconhece-se a vida, já que é a lei da vida a que funda, ademais, o 'conhecimento' da doença.

Essencialismo natural e ideal. As doenças são espécies ao mesmo tempo naturais e ideais. Naturais porque as doenças anunciam suas verdades essenciais; ideais à medida que elas nunca se dão na experiência sem alteração nem desordem. A primeira perturbação é trazida com e pelo próprio doente. À pura essência nosológica, que fixa e esgota sem resíduo seu lugar na ordem das espécies, o doente acrescenta, como outras tantas perturbações, suas predisposições, seu temperamento, sua idade, seu modo de vida e toda uma série de acontecimentos que, com relação ao núcleo 
essencial, constituem elementos acidentais e fortuitos. Para conhecer a verdade do fato patológico, o médico deve abstrair o doente (Sydenham, 1784; Sauvages, 1772, pp. 124-5). Paradoxalmente, o paciente é um fato exterior em relação àquilo pelo qual sofre; a leitura do médico não deve tomá-lo em consideração. Claro, é preciso conhecer "a estrutura interna de nossos corpos"; mas para melhor subtraí-la, e liberar sob o olhar do médico "a natureza e a combinação dos sintomas, das crises, e das demais circunstâncias que acompanham as enfermidades" (Clifton, 1742, p. 213). Não é o patológico que atua com relação à vida, como uma 'contranatureza', mas o enfermo com relação à própria enfermidade.

Estamos diante de um estatuto epistemológico arquitetado sobre os alicerces de um pensamento classificador e desencarnado, que cria também antolhos que ocultam o enfermo real e impõem uma conduta terapêutica álgida e reprimida. Aqui o olhar do médico não se dirige inicialmente a esse corpo concreto, a esse conjunto visível, a esta plenitude positiva que está diante dele, o enfermo: mantido à distância, este só é notado quando, a intervalos ditados pela natureza, o médico o percebe fragmentado numa sucessão de lacunas, onde aparecem como em negativo "os signos que diferenciam uma enfermidade de outra, a verdadeira da falsa, a legítima da bastarda, a maligna da benigna" (Frier, 1789, p. 113). No espaço fundamental da enfermidade, os médicos e os enfermos não estão implicados de pleno direito; são tolerados como tantas outras perturbações dificilmente evitáveis: (Foucault, 1972, pp. 6-19)

o papel paradoxal desta medicina consiste sobretudo em neutralizálos, em manter entre eles o máximo de distância para que a configuração ideal da enfermidade, entre seus dois silêncios, e o vazio que se abre de um a outro, se faça de forma concreta, livre, totalizada enfim em um quadro imóvel, simultâneo, sem espessura nem segredo, onde o diagnóstico se abre por si mesmo, sobre a ordem das essências.

Esse modelo epistemológico era coerente com a moldura ideológica que se impunha como exigência do pensamento hegemônico na França napoleônica: o liberalismo nos planos econômico e político. Nada mais lógico que a produção do saber médico tivesse também como matriz ideológica o liberalismo científico. Pois bem, eram justamente esses liberalismos que atuavam como obstáculo ao surgimento da medicina clínica moderna na França (idem, ibidem, pp. 37-52). Veremos adiante que este fosso gelado que separa sujeito e objeto (humano) de pesquisa tem paralelo com a pulsão esquizóide que fende a integridade psíquica do pesquisador, guiado pelo pressuposto de que, em benefício da boa razão, impõe-se protegê-la contra os 
vícios da afetividade. Nesta aporia iria se alicerçar a premissa epistemológica do estatuto da nova ciência médica brasileira em sua fase de decadência. Embora interessante a tarefa de buscar a fundamentação teórica e empírica desse fenômeno em ampla perspectiva, não me cabe aqui fazê-lo. De qualquer maneira, ela está sendo realizada de diferentes prismas por numerosos autores, com desdobramentos até os tempos atuais. Basta lembrar as críticas sobre objetos como monetarismo bastardo da economia da oferta, individualismo possessivo, neoliberalismo do estado mínimo, positivismo nas ciências sociais, alienação ontológica, determinismo espiritualista, falsificação da consciência, dicotomia entre julgamento de valor e julgamento de realidade, dentre outros temas correlatos (Kapp, 1966; Tsuru, 1964; Kozlik, 1968; Braverman, 1977; Blackburn, 1982; Packard, 1965; Villarreal, 1984; Monteiro, 1975; Macpherson, 1970; Lukács, 1979; Pappenheim, 1965; Monzani, 1995; Rouanet, 1985; Simmel, 1993; Rieser et alii, 1970; Durkheim, 1970; Gorz, 1964). É bastante conhecido o estudo da transposição do liberalismo ao contexto político e cultural brasileiro, na transição da monarquia para a República (Nogueira, 1984; Sevcenko, 1985; Schwarz, 1990, 1977). Para o fim a que me propus, é suficiente mencionar que o liberalismo brasileiro representa um caso particular de desvio em relação à norma geral. Em outras palavras, a maneira como o liberalismo científico perverteu o ensino e a pesquisa na medicina se apresenta como 'sintoma', como enunciado retórico que se define no papel de corpo estranho na estrutura de um organismo concebido para atuar como sistema coerente. É o dispositivo construído ad boc pelas elites dominantes no Brasil para perpetuar, pelo autoritarismo excludente, a vigência de seus interesses restritos. Conforme diz Monteiro (1975, pp. 170-210), a propósito da adaptação da ideologia de Hume ao meio inglês: "O enunciado retórico é o lugar de uma desarticulação, de uma desestruturação, da perda de certas características de sistematicidade. Interrogar-se sobre a significação dessa perda é o mesmo que perguntar de que esse enunciado é sintoma."

O fracasso do ensino e da ciência médicas no Império assinala antes de mais nada a ausência de um sistema de educação nacional. O ensino primário é insuficiente e ruim, o superior é anacrônico e falho, e, à exceção do Colégio Pedro II e de outras poucas iniciativas provinciais, não poderia preencher o hiato. $\mathrm{O}$ pior, porém, é que os estudantes não querem "seriamente aprender, mas simplesmente ganhar um título que os habilite a escalar as posições elevadas e o conforto da vida". Essa afirmação foi feita em 1882 por Ramiz Galvão em relatório oficial sobre a Faculdade de Medicina do Rio de Janeiro. Os professores eram, na maioria, mal remunerados e, não tendo condições para se preparar, eram meros repetidores de compêndios. "Embora, nas faculdades de 
medicina, certos professores (como Cláudio Velho da Motta Maia) insistam na excelência do ensino teórico - de resto, no caso, e particularmente na acepção em que era tomado, o menos importante -, e haja referência sobre notáveis qualidades de alguns professores de direito, a média dos depoimentos não exalta a qualidade do ensino" (Barros, 1986 pp. 208, 221-2). De modo geral, até a década de 1930 , não se dá ao ensino uma orientação científica própria. Os alunos deixam de comparecer às aulas, certos de que irão encontrar no compêndio o que deixam de ouvir nas aulas. O compêndio é um dos grandes inimigos do ensino. O governo intervém no conteúdo do ensino, dependendo de seu arbítrio suspender doutrinas que considere perigosas e subversivas. Sem liberdade de cátedra, professor e aluno são convidados à indolência. O professor, à força de repetir, ano após ano, a mesma 'lição', numa enervante rotina, não se atualiza, não estuda - às vezes nem sequer pensa mais. Tal ambiente não podia favorecer a investigação, a criação original, sem o que não se pode falar seriamente em estudos superiores. Durante todo o Império e até a década de 1930, continua a resistência contra a organização moderna do ensino e da pesquisa científica, o que se traduz na oposição à criação da universidade, sobretudo a de modelo germânico, mais próximo do ideal da criação autônoma da ciência. Seus principais opositores utilizam ora argumentos do catolicismo ultramontano, fundamentado na cloutrina da bula Syllabus (1864) e do Concílio Vaticano I, ora argumentos positivistas ou extraídos de outras versões conservadoras do liberalismo. Com o descrédito do positivismo, passaram a prevalecer os argumentos dessas últimas versões liberais. Entre os mais ferrenhos opositores do projeto universitário, até 1884 , estão os principais dirigentes da Faculdade de Medicina da Bahia (idem, ibidem, pp. 356-68). Não é de se estranhar, portanto, que tenha brotado fora dela e em conflito com ela a nova ciência médica brasileira, síntese das condições singulares locais com a ousadia de pesquisadores autóctones e a espantosa solidariedacle de sábios estrangeiros de formação alemã e inglesa. É impossível explicar de maneira isolada e mecânica essa emergência imprevisivel (clinâmen), pois estamos diante de um "desvio de forma" (Gestalt switch), de acordo com Popper (1972, pp. 52-4), em relação ao padrão determinístico vulgar. Segundo este padrão, tudo se passa como efeito imediato de funcionalidades ditadas pelo aparelho estatal ou por uma classe dominante. Contrarianclo o ingênuo reducionismo da vulgata marxista, este grupo baiano de vanguarda rompeu o cerco de uma certa lógica simplificadora, e, buscando mediação em outros elementos e valores além do conflito entre as classes sociais, conseguiu se afirmar temporariamente no ambiente hostil em busca de reconhecimento, 
legitimação, recompensa, renovação intelectual e transformação de políticas públicas. Muito antes da célebre carta que Engels escreveu a J. Bloch em 1890, os médicos da Escola Tropicalista Baiana provaram avant la lettre que a produção e a reprodução na vida real não é o único elemento determinante da história. Sua própria história demonstrou que afirmar o contrário "transforma o princípio da determinação econômica em última instância em uma frase sem sentido, abstrata e absurda" (Marx e Engels, 1971, pp. 76-9). Não obstante seu impacto histórico, esta experiência se esgotou em prazo relativamente breve, como a trajetória fulgurante e fugidia de um meteoro. Talvez porque seus intelectuais não tenham tido condições de "exercer as funções de direção e de prover um mínimo de densidade de organização", de modo tal que "essa autodefesa concertada" pudesse transformar o processo de "subversão da realidade" no embrião de um grupo que então, sim, buscaria os caminhos da "subversão pela vontade" (Ferreira, 1986, pp. 284-94). Esta seria a única possibilidade de ele se constituir em núcleo de uma revolução científica conseqüente. No caso, ela não se completou, por ausência de outros elementos necessários à ação hegemônica do novo espírito científico.

O malogro de todos os projetos de reforma do ensino superior apresentados até 1911, assim como o hiato que se prolonga até a década de 1930 , pode ser atribuído ao triunfo do liberalismo reacionário, favorável à 'desoficialização' do ensino. Este vazio não permitiu que se criasse "um grande centro de vida intelectual nacional", que viesse a derrotar a insuficiência da vida universitária e a mediocridade científica e pedagógica (e mesmo moral, por vezes) dos professores oficiais" (Gramsci, 1968, pp. 141-57). Este discurso liberal reacionário, ao proclamar que a pesquisa científica autônoma não corresponde aos interesses do país, na verdade oculta o objetivo de manter inalterado o status quo. Por trás da retórica de que o único interesse que importa está na formação profissional imediatista esconde-se uma medicina em crise. A retórica é o sintoma de um mal crônico: uma tecnologia médica rudimentar, afastada do mundo real, entregue a um poder médico elitista, cujo saber se exercita em grande medida à míngua de requisitos profissionais (Barros, 1986, pp. 222-440; Edler, 1992; Luz, 1982; Azevedo, 1994, pp. 233-300; Ribeiro, 1979; Nava, 1947; Costa, 1979).

Pesquisa meticulosa de Figueirôa (1992, pp. 24-33) revela que exceção a este quadro seria a introdução no Brasil das ciências geológicas entre o final do século XVIII e começos do século XIX. Mesmo assim, acrescenta a pesquisadora, seria necessário aguardar o final do século XIX para que fosse criada uma escola de minas e para vencer outras limitações do ambiente da época, cujos traços dominantes impunham às geociências um tipo de 
modernização de caráter exterior e eclético, "de fora para dentro" e "de cima para baixo", com ênfase na extração mineral até à exaustão das reservas, e não na localização e quantificação (pesquisa) de possíveis jazidas, cuja descoberta era atribuída na época ao acaso. O século XIX trouxe algumas mudanças, mas, em matéria de pesquisa científica, houve pouca coisa digna de nota. É verdade que se faziam obras de engenharia com alguma base técnica, aprendida nas escolas profissionalizantes isoladas e registrada em manuais traduzidos de fora. Havia algo de tecnologia, mas em forma de receita. Nada muito complexo ou criativo. A ciência possível no Brasil da época (ainda uma pré-nação) era encarada de tal maneira que não poderia apresentar as características aludidas. Não obstante, Figueirôa ressalta que, nas ciências da saúde, pesquisadores brasileiros e estrangeiros da época eram, em geral, merecedores de admiração, pois acompanhavam o que se pesquisava nos grandes centros europeus mais atualizados. Este é um bom argumento, válido quando nos referimos à plêiade de pesquisadores reunidos em torno da Escola Tropicalista Baiana, e depois à equipe de Oswaldo Cruz. Eles contribuíram para os progressos das ciências de seu tempo, mas deixaram poucos sucessores. Ademais, seria injusto nivelá-los aos "homens de ciência" que defendiam teorias racistas ou meramente organicistas que se curvavam ao determinismo de bronze da herança racial, tese já em desuso na Europa. Outro entrave para o avanço científico foi a influência exagerada do positivismo. Embora seja lícito reconhecer que o positivismo foi um fator de resistência do pensamento brasileiro ao ecletismo conservador, doutrina dominante na época, o fato é que o positivismo não só logo foi refutado por importantes homens de cultura de então, como também já não desfrutava de nenhuma guarida nos meios intelectuais sérios da Europa. Caberia, portanto, indagar por que razão essas correntes culturais retardatárias impregnavam os meios letrados do período. Isso nos leva a uma investigação da dinâmica da formação desses meios letrados, o que implica recuar ao período imediatamente anterior - a primeira metade do século XIX. A relativa rarefação do pensamento iluminista talvez seja uma primeira aproximação de hipótese explicativa. Um traço marcante desse pensamento pré-esclarecido é que não tivemos, salvo as exceções de praxe, uma tradição densa e contínua de pensamento teórico. Uma das causas é a falta de recursos para pesquisa. Mesmo nas áreas consideradas 'práticas' e 'úteis', as pesquisas teóricas deixam muito a desejar.

Em todo caso, era possível vislumbrar as sementes que iriam brotar. Vale ressaltar que a tentativa de vincular a ciência à medicina, expressa na reforma do ensino oficial introduzida pelo governo em 1832, não chegou a se completar no século XIX. A resistência 
à mudança era tamanha que não foi vencida sequer pelas inovações introduzidas a partir de 1879 com a importante reforma de Sabóia, a qual, entre outras novidades, criou, em 1882, a disciplina de anatomia patológica na Faculdade de Medicina do Rio de Janeiro. $\mathrm{Na}$ verdade, esta disciplina não era novidade no Brasil, pois a patologia experimental já era ministrada e praticada há várias décadas pelos médicos pioneiros da Bahia. Essas idéias tinham origem em médicos de formação germanista. Eles conheciam as mais recentes conquistas das ciências médicas da França, em particular o pensamento e as experiências de Bichat, Claude Bernard, Pasteur e outros, assim como os avanços da pesquisa científica básica na Alemanha e na Grã-Bretanha. No que estavam à frente de seu tempo. Já em meados da década de 1840, Domingos Marinho Azevedo Americano (1813-51), retornando de viagem de estudos a Paris, Berlim e Edimburgo, que se prolongou por três anos, considerou "indispensável" o conhecimento dos idiomas francês e inglês, e "importante" o de alemão, em nossas faculdades de medicina. Seu argumento baseou-se no fato de não haver literatura médica em português. "Nossa ciência sendo toda emprestada, como é, sendo nos livros europeus que vamos buscar todo o nosso saber desde as primeiras idéias da instrução elementar até o ensino superior das academias, a ignorância das principais línguas da Europa é uma falta imperdoável" (Americano, 1845, p. 184). Mas os projetos de reforma do ensino médico inspirados nesta Memória foram derrotados, em grande parte pelo interesse conservador em manter o clientelismo e o patronato na Faculdade de Medicina do Rio de Janeiro. Esta resistência pode ser simbolizada na atuação de José Martins da Cruz Jobim (1802-78), professor da faculdade e senador do Império, que, em 1863, no auge da crise do ensino médico, critica o empirismo e a fisiologia experimental como ameaças ao status profissional e ao poder político da elite médica dominante na corte imperial (Edler, 1992, pp. 53-6, 60-84, 148-9). Mas a crise quebrava a unidade ideológica da elite, de onde se alçavam vozes que combatiam a "pasmosa ousadia" dos que buscavam conhecimento de maneira diletante, que "é também a origem de nos conservarmos indefinidamente medíocres em matéria de ciência, nada produzindo de original aqueles que de tudo se ocupam com grande proficiência" (Figueiredo, 1874, p. 89). O autor deste protesto, Carlos Moncorvo de Figueiredo (1846-1901), foi um dos fundadores da Policlínica Geral do Rio de Janeiro (1881), um empreendimento particular, voluntarista e de caráter filantrópico, voltado para a assistência às populações carentes e para a pedagogia científica, inegavelmente um marco na luta contra a mentalidade reacionária dominante (Santos Filho, 1991, p. 101; Edler, 1992, pp. 220-7). Destacam-se nesta iniciativa pioneira os criadores da revista União Médica, o mais longevo e importante 
órgão da imprensa médica independente em circulação no Rio de Janeiro no final do século XIX. São eles: Júlio Rodrigues de Moura (1839-92), José Cardoso de Moura Brasil (1846-1928) e Antônio José Pereira da Silva Araújo (1853-1900). Seja como médicos, publicistas, professores ou pesquisadores, estiveram na vanguarda do exercício da medicina popular e da luta pela reforma do ensino médico e universalização do debate teórico com base na pesquisa em fisiologia experimental, parasitologia e demais disciplinas cientificas voltadas para a realidade brasileira da época. Não era fortuito: eles tinham sido inoculados pelo pensamento precursor do grupo da Gazeta Médica da Babia (Edler, 1992, pp. 171-2).

\section{Uma nova visão teórico-experimental}

O novo espírito médico surgiu, com o século XIX, vinculado ao descobrimento da anatomia patológica. Com esta descoberta, entra em crise a medicina cultivada durante os 150 anos anteriores a Bichat. Nesta medicina em crise, o olhar médico vincula-se a uma clínica e a uma anatomia meramente funcionais, limitadas em suas formas e manifestações, porque presas ao exame da superfície dos tecidos e a sintomas de enfermidades vistas como objeto passivo. Facilmente ela descamba para a tautologia e o verbalismo enfadonho. Classificativa, fragmentária, restrita a aspectos de procedimento, incapaz de enxergar causas ocultas e de interpretar o invisivel, esta medicina recai na descrição positivista e no discurso plano. Bichat rompe com a platitude e incorpora a espessura dos tecidos, dos órgãos, dos elementos que os diferenciam na profundidade do interior do corpo. Sua ciência é esférica. A partir de uma abordagem que privilegia a análise dos elementos reais e concretos do organismo, dissocia a complexidade funcional em simplicidades anatômicas. Se os elementos anatômicos são isolados por 'abstração', nem por isso são menos reais e concretos. Tendo escolhido um caminho aparentemente positivista, Bichat verticaliza o olhar, funde a anatomia com a fisiologia, incorpora o cálculo matemático ao conhecimento incerto e ao estudo combinatório dos elementos, e mantém uma atitude reflexiva que conduz a análise a um mergulho ontológico no âmago da enfermidade e do todo do organismo humano (Foucault, 1972, pp. 62, 96-105, 125, 133-49, 202-3).

Ao erigir a anatomia patológica como técnica do cadáver, Bichat confere à noção de morte um estatuto científico rigoroso, mais instrumental. Com seu domínio conceptual, a morte passa a ser uma linha vertical e absolutamente tênue que une, ao cortá-las, duas séries de elementos: a dos sintomas e a das lesões. Com Bichat, distinguem-se pela primeira vez duas ordens de fenômenos: as manifestações contemporâneas da doença e os antecedentes da morte. Pode-se então ter um entendimento melhor de sua natureza: 
ela é múltipla e está dispersa no tempo. Não é mais este ponto absoluto, a partir do qual os tempos se detêm para voltar atrás. Como a doença, está presente no tempo e no espaço. Na morte natural, primeiro se extingue a vida sensorial, a que se seguem outras mortes em cadeia no tempo e no espaço. Esta cadeia tem três centros essenciais: coração, pulmões e cérebro (idem, ibidem, pp. 143-6).

A vida, a doença e a morte constituem agora, na visão de Bichat, uma trindade técnica e conceptual. Rompe-se a velha continuidade pela qual a vida é ameaçada pela doença, e a doença, a presença aproximada da morte. Em seu lugar, articula-se uma figura triangular cujo cume é definido pela morte. Do alto da morte podem se ver e analisar as dependências orgânicas e as seqüências patológicas. Em lugar de ser o que havia sido durante milênios, esta noite na qual a vida se apaga, na qual se confunde a própria doença, a morte está dotada agora deste grande poder de iluminação, que domina e traz à luz ao mesmo tempo o espaço do organismo e o tempo da doença. O privilégio de sua intemporalidade vira instrumento técnico que captura a verdade da vida e a natureza de seu mal. A morte é a grande analista que mostra as conexões desdobrando-as, e faz rebentar as maravilhas da gênese no rigor da decomposição. O olhar médico passa a ser de um olho que viu a morte em sua plenitude. "Grande olho branco que desata a vida" (idem, ibidem, pp. 146-7).

Bichat fez mais do que liberar a medicina do medo da morte. Integrou esta morte no conjunto técnico e conceptual onde ela obtém seus caracteres específicos e seu valor fundamental de experiência. Até então, por mais demorada que fosse a observação dos sintomas, estes se sucediam de maneira confusa, pois, não vinculados a nada, ofereciam uma série de fenômenos incoerentes. Abertos alguns cadáveres, logo desaparecerá a obscuridade que tão-só a observação não tinha podido dissipar. "A noite viva se dissipa com a claridade da morte" (idem, ibidem, p. 149).

A doença destaca-se da metafísica do mal, com a qual estava aparentada há séculos, e encontra na visibilidade da morte a forma plena na qual seu conteúdo aparece em termos positivos - positivo entendido em sentido lato. Pensada com relação à natureza, a doença era o negativo indiscernível, cujas causas, formas e manifestações só se ofereciam de viés e sobre um fundo sempre rechaçado; percebida com relação à morte, a doença faz-se exaustivamente legível, aberta sem resíduo à dissecação soberana do olhar e da linguagem. Era mister abrir a linguagem a todo um domínio novo: o da correlação perpétua e objetivamente fundada do visível e do enunciável. Definiu-se então um uso absolutamente novo do discurso científico: costume de fidelidade e de obediência incondicionadas ao conteúdo polifacético da 
experiência - dizer o que se vê —; mas também costume de fundação e de constituição da experiência - dar a ver dizendo o que se vê -; por conseguinte, era mister situar a linguagem médica neste nível, aparentemente muito superficial, mas, na verdade, muito profundamente arraigado, onde a fórmula da descrição é ao mesmo tempo gesto de descobrimento. $\mathrm{E}$ este descobrimento implicava, por sua vez, como campo de origem e de manifestação da verdade, o espaço discursivo do cadáver; o interior revelado. "A constituição da anatomia patológica na época em que os clínicos definiam seu método não é da ordem da coincidência: o equilibrio da experiência quer que o olhar pousado sobre o indivíduo e a linguagem da destruição repouse sobre o fundo estável, visível e legível da morte" (idem, ibidem, p. 200).

A partir dessas descobertas pode-se compreender a importância da medicina para outras conquistas aparentadas: a construção do saber e da linguagem fundados na consciência da finitude do homem; o processo pelo qual o homem toma conhecimento positivo de si mesmo; a lei profunda da relação do homem com a morte permite um discurso científico sob uma forma racional; abre-se a fonte de uma linguagem que se desdobra indefinidamente no vazio deixado pela ausência dos deuses (com sua morte, Empédocles representa o último rompimento do mediador com os deuses, afirmando sua individualidade humana radical); a constituição das ciências do homem; e a invenção da experiência lírica (notadamente em Holderlin, Rilke e Nietzsche) como resposta crítica à razão instrumental. Por outro lado, a investigação vertical do positivismo faz aparecer uma série de figuras que estavam em jogo na sua gênese e que são liberadas contra ele: (idem, ibidem, pp. 201-3): "os poderes originários do percebido e sua correlação com a linguagem, nas formas originais da experiência; a organização da objetividade a partir dos valores do signo (e portanto da construção subjetiva da imagem e do conceito); a estrutura secretamente lingüística do dado; o caráter constituinte da espacialidade corporal; e a importância da finitude na relação do homem com a verdade e no fundamento desta relação".

Vale ressaltar que os êxitos da comunidade científica européia não foram homogêneos nem contínuos. "Na França, talvez como conseqüência da crise enfrentada pelo sistema de ciência e tecnologia depois da era napoleônica, motivo de dramáticas denúncias e manifestações como a de Louis Pasteur (1822-95) já no avançado 1860 , o diletantismo e o amadorismo continuavam a pontificar como um típico entusiasmo intelectual das classes altas, que fundavam por todo o país, e até nas colônias, as Sociétés des Savants" (Baiardi, 1997, p. 166). Enquanto isso, ganham relevo na Alemanha as faculdades de medicina, pioneiras no ensino de base científica e na pesquisa experimental (idem, ibidem, p. 162; 
Edler, 1992, pp. 234-40). No Brasil, malgrado a resistência obscurantista das classes altas, não se pode considerar como desprezível a recepção a essas idéias novas (Santos Filho, 1991, pp. 39-43, 74-6; Edler, 1992).

Manuel José Estrela (1760-1840) foi o primeiro professor da Escola de Cirurgia da Bahia. Cirurgião formado pelo Hospital Real de São José, de Lisboa, nasceu e morreu na Bahia. Seu grande feito foi ter traduzido de Bichat o livro Recherches physiologiques sur la vie et la mort, publicado em 1816 pela Tipografia de Manuel Antônio da Silva Serva, Salvador, sob o título Observações fisiológicas sobre a vida e a morte, obtidas pela indagação dos fenômenos da economia animal. Ao ser nomeado professor, recebeu por escrito de Picanço instruções que incluíam a de adotar o compêndio de cirurgia de $\mathrm{M}$. la Fay, autor de pouca expressão na França. A escola, criada em 1808, ficou esquecida, sem apoio do governo, tanto quanto sua congênere do Rio de Janeiro. É impossível fazer qualquer avaliação da influência exercida por esses autores. Ignora-se quase tudo sobre a escolaridade e o aluno. Desapareceram, em sua maior parte, os papéis referentes ao ensino médico na Bahia, desde seus primórdios. Em 1815, a escola foi transformada em Academia Médico-Cirúrgica da Bahia, onde foi professor José Avelino Barbosa, que nasceu na Bahia e lá morreu (1784-1838). Formou-se na Faculdade de Medicina de Edimburgo, percorreu a Alemanha e foi discípulo de Bichat em Paris. Entre 1829 a 1833, dirigiu a academia, onde foi professor de higiene a partir de 1832 .

$\mathrm{Da}$ academia, outro professor que chama a atenção é Antônio Pacífico Pereira (1846-1922), fundador da Gazeta Médica da Babia e autor de uma história da faculdade de Medicina da Bahia, Memória sobre a medicina na Babia (Imprensa Oficial do Estado, Salvador, 1923). Salvo este livro, fração de uma história que permanece incompleta e falha, não se conhece muito mais sobre a instituição, onde um incêndio, em 1905, consumiu o arquivo e a biblioteca.

O médico Antônio Ferreira França (1771-1848), que nasceu e morreu na Bahia, lecionou até 1837 nesta faculdade as disciplinas de higiene, etiologia, patologia interna e terapêutica. Formou-se em matemática, filosofia e medicina (1798) na Universidade de Coimbra. Atentando para as datas de sua jubilação e do término de seu mandato de deputado geral no Rio de Janeiro, nota-se que são as mesmas. Isso atesta a ausência constante do responsável pela cadeira às aulas, com o que sacrificou o desenvolvimento do ensino e da ciência. Neste aspecto, não se distinguia dos outros professores, mal remunerados e divididos entre diversas atividades para complementar a renda. Dava aulas de aritmética, geometria e grego. Foi médico da Santa Casa da Misericórdia, diretor 
do Liceu Provincial da Bahia, vereador e deputado. Não encontrou tempo para publicações. Deixou apenas um manuscrito de "preleções de geometria" e projetos e pareceres legislativos. Esta é a razão pela qual merece ser lembrado aqui. Apresentou à Câmara dos Deputados do Império projetos que não foram aprovados, tais como: criação de uma universidade no Rio de Janeiro; transformação do Brasil em República; concessão de liberdade aos nascidos de ventre escravo; direito de a mulher habilitar-se ao exercício da profissão médico-cirúrgica. Liberal radical e sonhador, era conhecido por sua personalidade espirituosa e muitas vezes bizarra. Talvez mais um intelectual promissor esterilizado pelas condições precárias do meio.

Em 1812, o cirurgião português Joaquim da Rocha Mazarém (1775-1849), professor da Escola de Cirurgia do Rio de Janeiro, publicou do mesmo livro de Bichat traduzido por Manuel José Estrela outra versão sob o título Indagações fisiológicas sobre a vida e a morte.

Estes casos de sintonia com os avanços do pensamento científico estrangeiro podem ser considerados excepcionais na comunidade médica brasileira, até o final do século XIX. Fica a impressão de que caíam no vazio, salvo por uma ou outra manifestação isolada de busca de atualização, como foi a tese de doutoramento que Miguel Couto defendeu em 1885 na Faculdade de Medicina do Rio de Janeiro, tratando Da etiologia parasitária em relação às moléstias infecciosas, inspirado em Pasteur (Santos Filho, 1991, pp. 36-7).

A norma geral era outra. A hegemonia ideológica estava centrada na Sociedade de Medicina do Rio de Janeiro (embrião da Academia Imperial de Medicina), fundada em 1829. Um de seus principais dirigentes, o já citado conselheiro Jobim, encarna cabalmente essa ideologia. Ficou célebre sua controvérsia com Otto Edward Henry Wücherer (1820-73) (Luz, 1982, pp. 121-37). Jobim estuda uma doença conhecida popularmente na época como amarelão, opilação ou cansaço, e por ele denominada hipoemia intertropical, no 'Discurso sobre as moléstias que mais afligem a classe pobre do Rio de Janeiro', publicado em 1835 (Wücherer, 1866, p. 29). O autor, expoente da elite médica do Império, coerente com a escola francesa especulativa, entende que a doença era causada por miasmas e outras múltiplas causas geográficas, e, sobretudo, por causas de ordem social, figurando entre estas a desordem da cidade e de suas instituições e a degradação moral das populações pobres, em particular dos escravos. Em outras palavras, ele enumera efeito se os toma como causas. Desprezando a pesquisa e o estudo de causas precisas, desconhece o agente etiológico de cunho biológico, cuja produção é confundida com condições favoráveis à sua reprodução. O escravo é visto não como homem doente, mas como 
"causa de desordem, doenças e brutalidades", ou como transmissor de "doenças próprias de suas disposições hereditárias" (Machado, 1978, pp. 354-6). Trabalha-se com a reprodução da doença ao modo da reprodução da dominação político-ideológica de um grupo social (Luz, 1982, pp. 126-7).

Rompendo com o discurso hegemônico da época, Wücherer (1866), da Escola Tropicalista Baiana, defende a necessidade de distinguir entre anemia e hipoemia. Considera a deficiência alimentar causa da anemia, mas diz que é necessário fazer uma diferenciação entre a causa de uma e de outra doença. Segundo Luz (1982, p. 130):

Para isto faz um diagnóstico diferencial baseado na anatomia patológica, menciona o agente etiológico (Ancylostoma duodenale) e relata que este foi unicamente encontrado em indivíduos falecidos de cansaço ... ou no decurso da moléstia. Esta ordem (falecidos no decurso da moléstia) indica a ordem presente em seu método de conhecimento. A ordem seria: inicialmente descoberta do agente etiológico através da autópsia; em seguida através de uma evolução detalhada das fases que a doença atravessa nos portadores, e do uso de diagnóstico diferencial; por fim, novo retorno à autópsia, no sentido de buscar uma confirmação de sua teoria. Descreve o verme, seus costumes e sua localização no corpo humano e termina por explicar que a anemia que verifica na opilação é efeito da subtração de sangue pelos vermes. Assim, ao determinar a causa, nomeia a doença: ancilostomíase. Notese que o nome anterior da doença — hipoemia - está ligado ao empobrecimento do sangue, que é tomado como causa; na realidade não passava de um efeito. Estas inversões causa-efeito serão uma constante ao se analisar o modelo de conhecimento da escola em comparação com o da sociedade. Termina afirmando que à mudança da patologia deve seguir-se uma mudança na terapêutica, deixando perceber uma relação de dependência existente entre esses dois momentos de seu método

A partir da periferia da corte, o grupo liderado por Wücherer desencadeou uma revolução epistemológica que iria se propagar vinte anos depois até a capital do Império. Há muito o que pesquisar para se conhecer em profundidade a história deste homem e de seus companheiros de aventura intelectual e existencial, e elucidar os móveis íntimos que os motivavam e lhes conferiam força espiritual para enfrentar o ambiente hostil. Mas um elemento é decisivo na caracterização desse movimento original: os interesses que guiaram a escolha do objeto de suas pesquisas e dos seus principais beneficiários. Antes de mais nada, focalizou-se o interesse social na população de excluídos, em particular os escravos. Nunca no país a categoria médica havia escolhido como tema de estudo as doenças que afetavam a força 
de trabalho, e com a preservação de sua saúde. Não fazia parte das cogitações da classe senhorial brasileira o cuidado com a manutenção nem com a reprodução da escravaria. A tentativa de copiar a experiência das coudelarias humanas adotadas na América do Norte não prosperou entre nós. Trato deste assunto em outro lugar (Barros, 1997). Para a elite médica imperial, a população pobre, notadamente a escrava, era 'causa' de doenças: classificavase na categoria do risco, do perigo, da ameaça, do estorvo. Às vezes, era vista com o sentimento piedoso da caridade. Mesmo assim, guardando-se distância, procurando-se mantê-la afastada dos sãos, para não contaminá-los. A política de saúde, seja lá o que isso tenha significado na época, era a política de saneamento da cidade, para protegê-la da invasão dos bárbaros. E os intrusos deveriam ser segregados, já que eram indispensáveis para o trabalho manual, incompatível com o parasitismo das classes ociosas. Do ponto de vista terapêutico, não havia interesse em cuidar de escravo, pois os médicos eram, na sua maioria, pobres e precisavam de uma clientela que os remunerasse bem. Eram nômades, pois a sociedade também era pobre; ficavam pouco tempo em cada localidade do interior. Sofriam a concorrência dos práticos e charlatães, de baixa qualificação intelectual e de origem humilde, que cobravam ninharia pelas consultas.

$O$ interesse científico pelas doenças dos escravos, para não dizer inexistente, era ainda mais raro, às vezes movido por curiosidade em relação ao exótico; no melhor dos casos, era um interesse puramente abstrato. Era fácil de explicar pelas condições precárias da comunidade médica. Se no geral predominava o preconceito religioso contra o sangue, a anatomia, a higiene, a saúde do corpo, em favor da salvação da alma, a aversão ao trabalho manual levava à aversão à pesquisa experimental, fazendo do trabalho com cadáveres uma "medicina dos mortos" (Coni, 1952 , p. 35). A elite médica considerava a reflexão teóricoexperimental atividade de segunda ordem, quando não fantasma desagregador do status quo; preferia o discurso médico verboso, livresco, hermético, para disfarçar a ignorância e o gosto pelo poder sem mérito de conteúdo. A lógica da sociedade, regida por uma dialética da ambigüidade (Carvalho, 1988) e envolta numa atmosfera geral de incongruência ideológica (Faoro, 1974), fazia proliferar nas altas esferas do poder e no cotidiano das relações pessoais a conduta da impostura e da desfaçatez (Gledson, 1991). Vale dizer, as elites médicas buscavam mimetizar sem presença de espírito o figurino europeu mais em voga, mas sem escapar das armadilhas da realidade social (escravista e rústica) do país. Dinâmica paradoxal: expressava-se o impulso filoneísta de ajuste ao modelo de progresso justaposto de fora para dentro, mas limitado pelo desajuste das relações sociais anacrônicas (Pires, 1989, 
pp. 61-105; Luz, 1982, pp. 121-7; Edler, 1992, pp. 61-84; 18597). Tomada pela crise da profissão, do ensino e da pesquisa, a elite médica imperial buscava equacionar as questões colocandoas não num plano estritamente corporativo, mas procurando integrar os interesses subalternos e lhes dar um lugar orgânico de expansão subordinada, isto é, no interior do próprio conjunto das instituições da sociedade civil e do aparelho jurídico-político e repressivo (Gramsci, 1991; Salles, 1996). Isso explica por que pululavam o diletantismo, a arbitrariedade, o compadrio, o clientelismo, o discurso laudatório da autoridade, a cooptação dos setores e indivíduos independentes pela máquina burocrática. Ora, na ausência de um espírito de escola (Nava, 1947, pp. 71-87), alguns grupos dissidentes acabavam sempre por ser neutralizados e assimilados, até com sua própria conivência, aos interesses "gerais" e "nacionais", num plano "universal" de hegemonia da oligarquia dominante (Salles, 1996, pp. 46-7). Como veremos, desse fenômeno não iria se desvencilhar o grupo com o qual a medicina brasileira conquistou pela primeira vez sua independência.

O rompimento com a mentalidade acadêmica tradicional deveuse à Escola Tropicalista Baiana (Coni, 1952; Peard, 1993; Luz, 1982; Pires, 1989; Santos Filho, 1991, pp. 176-7), criada por volta de 1860 . Seu programa de pesquisas, orientadas pelo método experimental, abarcava disciplinas como anatomopatologia, parasitologia, epidemiologia, bacteriologia, microscopia e fisiologia clínica. É importante notar que essas pesquisas, de que se tem notícia desde a década de 1840 , se realizavam fora dos objetivos da Faculdade de Medicina e do aparelho estatal, e por ambos amiúde hostilizadas. Sensível à realidade social de seu tempo, os fundadores dessa escola interessaram-se pelo estudo de enfermidades epidêmicas, doenças típicas das populações pobres, princípios ativos da farmacopéia natural, particularmente da fauna e flora brasileiras, e outros assuntos de alcance social, sempre de acordo com normas rigorosamente científicas. Seus trabalhos sobre doenças dos escravos africanos e de taxonomia ofiológica são considerados pioneiros no Brasil. O grupo divulgou os primeiros trabalhos significativos de medicina experimental no Brasil por intermédio da Gazeta Médica da Babia, cuja publicação, iniciada em 1866, foi interrompida em 1908.

Foram eles que, por sua própria conta e risco, abriram na Bahia caminhos inovadores no campo da pesquisa experimental e laboratorial e da assistência médica popular, voltando-se para as necessidades dos grupos sociais desprezados pela elite e mantendo contato regular com os conhecimentos mais atualizados em desenvolvimento no exterior. A Gazeta Médica da Babia publicava trabalhos de alto valor científico, desenvolvidos com originalidade por médicos locais, e mantinha intenso intercâmbio 
com pesquisadores estrangeiros de grande prestígio, que não hesitavam em reconhecer seus méritos e suas descobertas revolucionárias para a ciência da época. Pela primeira vez no Brasil e no mundo, foram relatadas epidemias como a febre amarela e o cólera-morbo; etiologias de doenças como a ancilostomíase e a filariose; sintomatologias como a do envenenamento ofídico; e observações sobre o beribéri, o ainhum e outras afecções tropicais. Além do alemão Otto Edward Henry Wücherer, constituíram o grupo inicial o escocês John Ligertwood Paterson (1820-82) e o português José Francisco da Silva Lima (1826-1910). Há registro de notícias sobre as atividades de Philipe Pinel, que na França introduziu mudanças significativas no tratamento de doentes mentais e fez avançar, dentro dos quadros culturais da época, os conhecimentos em psiquiatria. O que impedia que essas iniciativas desbravadoras vingassem era a falta de grupos sociais dinâmicos que as apoiassem, e o descaso do aparelho governamental, que não dispunha de uma política pública que lhes conferisse caráter prioritário e alcance geral.

O exemplo da Gazeta Médica da Babia acabou frutificando na capital do Império. Principalmente após o término da guerra do Paraguai, quando a monarquia caía rapidamente em descrédito. Coincidiu com o constante pipocar de novidades científicas que vinham abalar as hipóteses mais sedimentadas. A herança médica colonial entrava em fase marcada pela rápida obsolescência e pela especialização em diferentes disciplinas. Diante do caráter moroso e mesmo estacionário das instituições oficiais, surge um espaço novo de crítica e revitalização. Ao lado das clínicas privadas, é a imprensa médica independente que aparece como instrumento fundamental para atualização e universalização do debate científico. Os periódicos independentes ajudavam a romper o monopólio do saber das instituições oficiais, estagnadas no espírito doutrinário. Passaram a incentivar um movimento capaz de aglutinar diferentes segmentos da corporação em torno de um programa de reformas do ensino e de novos campos de pesquisa peculiares à realidade brasileira. Uma ilustração dessas experiências, em grande parte incipientes e desarticuladas, merece referência. A descoberta da filária Chyluria e de seu hospedeiro Musca canaria, por Wücherer, foi confirmada na Casa de Saúde São Sebastião, de propriedade de Felício dos Santos e Hilário de Gouveia. E são os jornais e revistas independentes que dão conta dessas experiências, estabelecem os intercâmbios de concepções científicas entre diferentes grupos nacionais e internacionais, e contribuem para formar os consensos e dissensos em torno da adoção ou recusa de certos esquemas conceituais como cientificamente válidos (Edler, 1992, pp. 156-84). 


\section{Sol negro no crepúsculo da mestiçagem: a armadilha do racismo}

Mas este movimento tem vida curta: a partir de 1896, a Escola Tropicalista Baiana entra em decadência.

As pesquisas sobre beribéri são conduzidas com base em diferentes hipóteses, que contemplam desde causas parasitológicas e bacteriológicas até avitaminose $B$. Mas não se chega a nenhum resultado aceitável. Um de seus pesquisadores é o médico Raimundo Nina Rodrigues (1862-1906), que abandona o projeto quando constata que não existe, na Bahia, possibilidade de se efetuar pesquisa rigorosamente científica, por falta de pessoal especializado (principalmente bacteriologistas com sólida formação), equipamentos de laboratório (microscópios etc.), materiais e recursos à altura da nova ciência que se descortinava com as descobertas de Pasteur, Koch, Claude Bernard e outros. A questão do beribéri só viria a ser resolvida muitos anos depois, por meio de outro método, o bioquímico, que pressupõe o uso de tecnologia sofisticada, a qual, por sua vez, imprime ao saber médico um modelo apoiado numa estrutura industrial avançada, diferente do modelo proposto pela Escola Tropicalista Baiana, apoiado numa estrutura agrária atrasada. Assim, em 1936, William Henry Sebrell (1901-92), da Universidade de Columbia (EUA), descobre o agente etiológico do beribéri ao estabelecer que a carência de vitamina $\mathrm{B}^{1}$ é a causadora da doença (Luz, 1982, p. 164; Sebrell e Harris, 1954; Houaiss, 1979, pp. 1.1461-4).

Alarmado com os surtos de moléstias infecciosas, o governo baiano criou um instituto vacínico para suprir as deficiências dos laboratórios da Faculdade de Medicina. Todavia, cumprindo o vaticínio de Nina Rodrigues, que apontou as razões pelas quais a lei seria inexeqüível, o instituto nunca foi instalado (Coni, 1952, pp. 58-61).

Desde 1891, muito jovem, Nina Rodrigues havia obtido por concurso, na Faculdade de Medicina da Bahia, o cargo de professor substituto de medicina legal, especialidade meio médica, meio jurídica, que lhe daria ensejo de se voltar inteiramente para os problemas de biossociologia brasileira, tão das cogitações de seu espírito. Durante o exercício de suas funções docentes, não esmoreceu na crítica ao declínio do ensino acadêmico, que atribui à penúria de meios materiais que lhe destinam "os governos, desidiosos e mesquinhos em assuntos que se prendem à saúde dos povos" (idem, ibidem, pp. 62-7).

Em 1897, Nina Rodrigues aponta a decadência do ensino teórico e prático na Faculdade de Medicina da Bahia, afasta-se completamente das pesquisas junto à Escola Tropicalista Baiana e encerra a carreira de patologista de doenças tropicais. Este momento 
pode ser considerado o marco de encerramento da Escola Tropicalista Baiana, pois, ao redigir a memória histórica sobre a faculdade, Nina Rodrigues expõe as razões pelas quais não havia condições para que fossem realizados uma teoria, uma prática e um ensino médicos de acordo com o modelo médico sanitarista imaginado pelos fundadores do movimento médico tropicalista. A partir daí, Nina Rodrigues consolida uma produção intelectual que havia iniciado alguns anos antes e que vai influenciar todo o pensamento médico posterior. Com efeito, ele muda radicalmente o enfoque epistemológico de Wücherer, Paterson e Silva Lima. Enquanto estes buscavam nos cadáveres o substrato anatomopatológico capaz de explicar manifestações detectadas no nível da clínica médica, Nina Rodrigues, com seus estudos de antropologia criminal inspirados em Lombroso, buscava nos cadáveres substrato anatomopatológico que pudesse' evidenciar manifestações detectadas no nível social, como a criminalidade e a doença mental. Estudando a influência de Comte, Wundt, Spencer, Darwin e Galton, poderemos ver que sua obra, ao mesmo tempo que marca o fim da Escola Tropicalista Baiana, inicia um processo de aproximação com alguns dos interesses do Estado, em especial a instauração da política de controle das "classes perigosas" com base numa "cientificidade biológica". Com a eugenia, a intervenção estatal na sociedade propiciaria o aumento do poder dos médicos, em detrimento do poder da instância política e jurídica, ao mesmo tempo em que se postulava uma identidade do social e do biológico, em que o primeiro era explicado pelo segundo (idem, ibidem, pp. 56-7; Luz, 1982, pp. 164-72).

Suas idéias mestras são calcadas no sistema positivista criado por Auguste Comte e, no atinente às suas novas preocupações acadêmicas, inspiram-se principalmente nas teorias de Cesare Lombroso (1836-1909), em medicina legal, e de Wilhelm Wundt (1832-1920), em psicologia coletiva. Estes dois últimos autores são reconhecidos como expoentes do cientificismo positivista na Itália e na Alemanha na segunda metade do século XIX, cujos fundamentos foram tirados das teorias de Herbert Spencer (18101903), Charles Darwin (1809-82) e Francis Galton (1822-1911). Lombroso, que proclamou Nina Rodrigues "apóstolo da antropologia criminal no Novo Mundo" (Coni, 1952, p. 75), introduziu na criminologia positiva a noção de criminoso nato, que afirma que delinqüentes, loucos e agitadores políticos, entre outros indivíduos "anti-sociais", apresentam comportamentos desviantes porque são portadores de taras hereditárias. Wundt criou, em 1878, uma disciplina própria, a psicologia das multidões (Volkerpsycbologie), que estuda os indivíduos tomados de "delírio coletivo" sob o comando de um "guia", cuja superioridade é comprovada pelo fato de ser de cor branca e especificamente da "raça germânica", 
sendo que se classificam como patológicas as multidões de grevistas, revolucionários, místicos etc. (Luz, 1982, pp. 166-72; Geymonat, 1985, pp. 192-4, 198-9, 216-24, 225, 232-3; Buican, 1990, pp. 101-10).

Quanto à eugenia, lançada em 1865 na Inglaterra por Galton, sobrinho de Darwin, tem precursores como Karl Kautsky, George Vacher de Lapouge e, na Rússia, Max Levien. Foi introduzida na Alemanha, depois de 1890, pelos médicos Alfred Ploetz (18601940) e Wilhelm Schallmayer (1857-1919) sob o nome de higiene racial, que só passou completamente para a extrema-direita com a evolução global do país e por causa das possibilidades apresentadas por um Estado forte, capaz de impor nova moral científica, cujos arautos seriam sobretudo os médicos (Poliakov, 1974, pp. 197299, principalmente da p. 282 em diante; Dupeux, 1992, p. 181).

Ao se estudar a influência das variedades da teoria racial alienígena sobre o meio intelectual brasileiro, de 1860 até as primeiras décadas do século $\mathrm{XX}$, não se pode desconhecer o papel dos vulgarizadores da escola etnológico-biológica, que usavam o aparato ideológico de uma nova ciência, a antropologia física, para conferir base científica aos preconceitos preexistentes sobre o comportamento social dos não-brancos, da mesma forma como outros pesquisadores pretendiam encontrar provas da inferioridade mental dos negros nos resultados de seus testes de inteligência. A escola etnológico-biológica oferecia uma rationale científica para a subjugação dos não-brancos, sendo indiferente se em servidão legal ou não. Um dos mais importantes representantes da escola etnológica racista norte-americana, que teve influência direta entre os poucos etnógrafos e antropólogos ativos no Brasil, entre 1870 e 1914, foi Louis Agassiz, zoólogo suíço formado na Universidade de Harvard (EUA), que se tornou o mais famoso propugnador científico da poligenia na América. Veio ao Brasil em 1865 numa expedição científica. Três anos mais tarde publicou (com a mulher) um relato da viagem. Sua Journey in Brazil foi largamente citada no país e deu curso entre a elite às idéias de diferenças raciais inatas, de inferioridade das raças índia e negra e de "degenerescência" mulata (Skidmore, 1989, pp. 66-7).

Outra teoria determinista com a qual a elite letrada brasileira estava familiarizada foi a da escola racista histórica, cujos portavozes mais conhecidos eram o inglês Henry Thomas Buckle (182162) e o francês Joseph-Arthur (conde) de Gobineau (1816-82). Eles partiam da suposição de que a raça banca era permanente e inerentemente superior a todas as outras. Gobineau era muito amigo do imperador. Defensores de confusas doutrinas sobre a irremediável inferioridade racial dos não-brancos, que tiveram grande influência sobre a elite brasileira, foram o filósofo argentino José Ingenieros (1877-1925) e o fisiologista francês Louis Couty 
(1856-78). Este último, tendo trabalhado na Escola Politécnica e no Museu Nacional do Rio de Janeiro, foi crítico arguto das limitações da pesquisa científica no país e incentivador do desenvolvimento de uma ciência voltada para a realidade brasileira. Fundou um laboratório de fisiologia experimental em 1876, com o que a antropologia física passou a ser uma das primeiras disciplinas a serem reconhecidas no país. No entanto, as pesquisas concentraram-se no índio, utilizando técnicas européias de medição de crânios, ignorando-se por completo o estudo do negro, salvo pelo trabalho de Melo Morais Filho, que fez coleta do folclore afro-brasileiro, e pelas opiniões de seu diretor, João Batista de Lacerda, o qual, em escritos publicados em 1911 e 1912, apregoavá a extinção da raça negra e vaticinava, com base no pressuposto da superioridade da raça branca, mas sem nenhuma evidência científica, que seria inevitável o "branqueamento" da população brasileira. Perfilhavam suas idéias Ladislau Neto, antigo diretor do museu Nacional, Manuel de Oliveira Lima, Sílvio Romero, José Veríssimo, Afrânio Peixoto, o viajante Pierre Denis e o expresidente americano Theodore Roosevelt. $O$ mesmo viés existiu no Museu Paulista, onde seu diretor, o zoólogo Von Ihering, imigrante alemão, era pessimista quanto à possibilidade de sobrevivência dos índios primitivos no Brasil, a ponto de, em 1908, ter ficado dividido com a antinomia "extermínio dos indígenas ou dos sertanejos", tema de artigo que publicou na imprensa. Situação semelhante de negligência de estudos sobre o negro prevaleceu no Museu Paraense, fundado em 1885 e dirigido pelo imigrante suiço Emílio Goeldi (idem, ibidem, pp. 37-53, 73, 74, 75-94 e 267, n. 49; Santos Filho, 1991, pp. 177-8).

A terceira escola de pensamento racista em voga no Brasil era o darwinismo social. Partia, como vimos, das idéias de Spencer, Darwin e Galton, para quem, no processo histórico-evolutivo, como resultado da "sobrevivência dos mais aptos", as raças "superiores" haviam predominado, fazendo com que as "inferiores" estivessem fadadas a definhar e desaparecer. Os escritores racistas Gustave Le Bon e Victor de Lapouge eram muito populares entre os brasileiros. Artur Orlando, em Brasil: a terra e o bomem (Recife, 1913 , p. 12), explica as teorias racistas desses dois escritores sem ajuntar nenhum comentário crítico (Skidmore, 1989, pp. 6070 e 265, n. 36).

O primeiro estudo etnográfico sério e respeitável do afrobrasileiro por um brasileiro veio de Nina Rodrigues. Embora tendo morrido prematuramente, aos 44 anos, sua obra já o havia tornado figura altamente acatada e respeitada nos círculos culturais do Brasil. O que causa espécie, todavia, é que, sendo mulato, adquiriu notoriedade como o principal doutrinador racista de sua época. Foi muito lido por quem se interessava a sério pelo assunto racial, 
mas suas opiniões ficaram à margem da corrente principal do pensamento brasileiro. Poucos de seus contemporâneos podiam ignorar a questão negra no Brasil, mas poucos como ele correram o risco de adotar idéias racistas tão ortodoxas. Mesmo um de seus mais notáveis discípulos, o antropólogo Artur Ramos, reconhece as idéias errôneas e extremadas do mestre. Para explicar que a inferioridade do africano fora estabelecida fora de qualquer dúvida científica, apegava-se ao argumento positivista de que o elevado grau de inteligência das raças superiores era evidente pela simples observação empírica de que a civilização européia progredia tão rapidamente que seria impossível testar na prática a eventual validade da hipótese de que a inferioridade do negro era transitória, e não inata. Embora confessasse em Os africanos no Brasil (p. 25) que seus sentimentos nada tinham a ver com suas idéias científicas, até porque tinha "viva simpatia" pelo negro brasileiro, aplicava a teoria da inferioridade racial diretamente a seu trabalho de medicina legal. Revelava uma incoerência intelectual e uma duplicidade ética que talvez resultassem da falta de "bom preparo do curso de humanidades", assim como, na fase de produção científica, da falta de tempo suficiente para cultivar os autores clássicos (Coni, 1952, p. 68). Indiferente aos princípios éticos fundamentais de igualdade da espécie humana e de solidariedade moral para com seus semelhantes étnicos, e demonstrando espantosa cisão entre sua essência humana afetiva e seu frio raciocínio cerebral (Oliveira, 1991), Nina Rodrigues não vacilava em dizer que as características raciais inatas afetavam o comportamento social e deveriam ser levadas em conta por legisladores e autoridades policiais, para fins de controle da ordem dominante e de repressão do conflito, tendo em vista não a proteção de cidadãos detentores de direitos universais inalienáveis (consagrados desde o Renascimento, a Revolução Francesa e a Revolução Americana), mas a morte civil de entes inferiores, para preservar a dominação incontroversa das "raças brancas civilizadas". Ao fazer essa asserção, sem prova que a sustentasse, fingia adotar uma postura neutra e livre de valores, postura que apenas ocultava o desejo cortesão de ser reconhecido pela elite senhorial do Estado e da Academia que ele não se cansava de adular e que lhe retribuiu o favor em 25.10.1903 com a liturgia do banquete em cena aberta e com o panegírico estampado no jornal O Estado de S. Paulo, por ocasião de sua morte (Skidmore, 1989, p. 267, n. 50). Recomendava que se atribuísse a negros, a silvícolas e a alguns tipos de mestiços socialmente instáveis apenas uma "responsabilidade atenuada", status semelhante à do menor. Esta capitis diminutio aplicava-se igualmente a uma categoria de mestiços "degenerados", mas recuperáveis - com relação aos quais não se especifica o conceito operacional, nem a quem caberia decidir que cidadão determinado 
seria enquadrado nela. Agora, para os restantes "degenerados", só caberia o tratamento de absolutamente incapazes, categoria na qual o legislador do Código Civil de 1916 iria incluir os menores de 16 anos, os loucos de todo gênero, os surdos-mudos que não pudessem exprimir sua vontade, e os ausentes (artigo 5o). Notese que, no artigo $6^{\circ}$ deste código, a mulher casada foi incluída na classificação de "relativamente incapaz", ao lado dos menores cle 21 anos, pródigos e silvícolas (lei de 1962 retirou a mulher casada desta classificação). Num lance de esperteza, Nina Rodrigues criou uma categoria de mestiços de tipo superior, na qual, presume-se, incluiria a si próprio. Mas não escreveu uma única palavra sobre o direito dos "inferiores” à proteção contra os racistas da sociedade brasileira. Rendidos ao arbítrio dos "arianos civilizados", esses seres humanos "inferiores" estavam destinados a ser julgados segundo um único critério: sua presumida classificação racial. Nina Rodrigues fora mais longe do que a maior parte da elite senhorial brasileira. Sua sugestão não teve nenhuma influência sobre os responsáveis pela revisão do Código Penal, de 1890. Ele próprio lamentou essa falta de receptividade por parte de autoridades e legisladores. Numa época em que a genética não era uma ciência desenvolvida, e cientistas respeitáveis ainda discutiam se cruzamentos entre "raças" diferentes produziam "híbridos vigorosos" ou degenerados físicos, Nina Rodrigues inclinava-se por esta última posição, e citou Agassiz como autoridade em miscigenação. Associava-se desse modo com o mais importante dos teóricos norte-americanos da degenerescência do mulato. Trinta anos depois, importantes ideólogos do III Reich e do Estado Novo varguista iriam esposar sua opinião, convenientemente alargada para mobilizar emocionalmente multidões contra judeus e outros grupos não-arianos (Carneiro, 1995; Goldhagen, 1997). Por fim, Nina Rodrigues não trepidou em contradizer frontalmente a opinião da elite senhorial de que a miscigenação levaria, mais cedo ou mais tarde, a um Brasil "branqueado", selando a questão com o argumento do determinismo climático, afirmando peremptoriamente que "o clima intertropical é inóspito aos brancos" (Skidmore, 1989, pp. 74-80, 267-8, n. 52, 55).

Não é de estranhar, portanto, que, no Rio de Janeiro, estando já bem avançado o século XX, quando a psiquiatria despertaria $o$ interesse de médicos especializados na área, a disciplina seria estruturada sem o enfoque científico e o significado humano que tinham sido infundidos cem anos antes pelos abnegados estrangeiros fundadores da Escola Tropicalista Baiana. De lá havia sido transplantada uma semente na qual Nina Rodrigues efetuou uma mutação, a qual não poderia deixar de engendrar uma progênie aberrante. 
A experiência desses psiquiatras cariocas reunidos na Liga Brasileira de Higiene Mental foi comprometida pela introdução de noções pseudocientíficas e anti-sociais, calcadas em noções de purificação racial, receitas de esterilização sexual de indivíduos doentes, pregação da necessidade de eliminação da miscigenação étnica, exigência de proibição da imigração de indivíduos nãobrancos, recomendação de instalação de tribunais de eugenia e de salário-paternidade eugênico e outras aberrações inspiradas em preconceitos ideológicos nazistas, novidade na época (Costa, 1976).

Esses fatos demonstram que a evolução histórica nem sempre obedece a uma trajetória linear, como poderia sugerir uma idéia simplória de progresso.

\section{O fluir do tempo é fecundo}

O saber e a prática das ciências biomédicas no Brasil experimentaram grandes transformações ao longo da história. Não cabe aqui detalhar o que aconteceu entre o final do século XIX e os dias de hoje. O que se pode dizer, sem risco de errar, é que os problemas de saúde do povo continuam essencialmente sem solução. A literatura da década de 1990 é muito parecida com a da de 1980 e a das de 1970, 1960, 1950, 1940, 1930 e 1920, numa marcha regressiva que vai nos levar ao período que encerra nossa reflexão. Nossos problemas de saúde continuam essencialmente os mesmos: doenças causadas pela miséria e pela exclusão dos pobres dos benefícios do desenvolvimento geral da economia, da sociedade, dos costumes, da cultura, da tecnologia, das ciências (Cupertino, 1976). Continua prevalecendo a medicina curativa, lucrativa e sintomática, em detrimento da medicina preventiva, social e generalista. A política pública sanitarista perde terreno para a privatização dos serviços de assistência à saúde. No orçamento estatal de saúde, os gastos com vacinação e controle de doenças de massa cedem prioridade para os pagamentos a empresas particulares que enriquecem com o tratamento cada vez mais sofisticado e caro de doenças de uma minoria. Na prática, evita-se a saúde, promovendo-se a doença (Landman, 1982). O sistema de saúde está em crise (Mello, 1981). O complexo médicoindustrial continua impondo seus interesses ao conjunto da sociedade (Cordeiro, 1980). O grande capital monopolista continua colocando o lucro da mercantilização das necessidades básicas da população à frente das necessidades da demanda de alimentação sadia, moradia, transporte, previdência e bem-estar físico e mental (Kucinski e Ledogar, 1977). A formação dos médicos continua reclamando mais responsabilidade profissional e densidade teórica e menos diletantismo (Britto, 1995). A pesquisa científica continua precisando de mais adequação à realidade brasileira e 
menos improvisação e dependência externa (Benchimol e Teixeira, 1993). A sociedade civil continua em busca de autonomia (Capistrano, 1995). É mister equacionar a questão da saúde com os modernos recursos do planejamento estratégico (Testa, 1995). O aparelho estatal continua omisso e ineficaz.

Penso, porém, que muita coisa mudou no plano do pensamento contemporâneo. Esclarecer a natureza dele é fundamental para aprender com o passado e reconstruir o futuro contido no presente. Julgo que é fundamental olhar o passado a partir do presente. À luz do passado, o presente fica mais consistente do que parece. A luz do presente, o passado fica mais compreensível do que costuma ser. E, a partir dessas duas perspectivas, o futuro fica mais discernível como condição de possibilidades do que como predestinação determinística. Tudo isso pode conduzir a um curso de ação mais livre, criativo e fecundo do que tem sido nos últimos tempos.

Acredito que a história das ciências biomédicas no Brasil nos traz várias lições. Uma das mais importantes é que o processo de produção de conhecimentos se dá por meio de uma dupla ruptura, uma dupla descontinuidade, a descontinuidade histórica e a descontinuidade epistemológica (Castells e Ipolla, 1975, pp. 131224; Lecourt, 1972). A descontinuidade histórica consiste no efeito produzido pela emergência de uma nova disciplina científica na história do saber. No caso da medicina brasileira da segunda metade do século XIX, essa nova disciplina foi a clínica com base na anatomopatologia voltada para as doenças tropicais que afetavam as classes populares. Pode significar também a reformulação dos axiomas fundamentais de uma ciência já constituída, seja para ampliá-la, seja para substituí-la por outra. Vimos que, no caso da medicina tropicalista baiana, seu esgotamento correspondeu à substituição do trabalho com cadáveres para o tratamento clínico de doentes pobres pelo trabalho com cadáveres para o controle social de "raças inferiores", mediante o desenvolvimento de novas ciências, a medicina legal e a antropologia criminal.

A descontinuidade epistemológica consiste no efeito específico produzido pelo trabalho científico enquanto tal, em relação às evidências da percepção e do senso comum. Esta ruptura pode ser designada também com a categoria, emprestada de Bachelard (1977; 1967; 1934), de corte epistemológico. Wücherer efetua o corte epistemológico em relação à noção de miasma, proposto por Jobim como explicação para a etiologia da hipoemia intertropical, e introduz um conceito novo, captada da parasitologia, para explicar a causa da doença que ele passou a designar com o nome de ancilostomíase.

Em ambos os sentidos, a descontinuidade ou ruptura é indissociável da categoria complementar de obstáculo epistemológico. 
Jobim opunha resistência intelectual à nova ciência, a fisiologia anatomopatológica experimental, de um lado por ignorância do saber desenvolvido por Bichat. De outro, ele temia ver abalado tanto o status acadêmico da elite médica que ele representava na Academia Imperial de Medicina, quanto a autoridade política que encarnava como senador e conselheiro da corte.

O corte epistemológico realizado por Nina Rodrigues é de outra índole. Tem um sentido de avanço, quando é visto pelo ângulo da criação de uma nova ciência, ou de duas novas ciências, a antropologia e a medicina legal. De outro ponto de vista, verificase uma marcha à ré em relação à medicina sanitarista de caráter popular. Ou por outra, inaugura-se uma era de utilização do saber científico como instrumento de controle social das "classes inferiores", sob a legitimação icleológica da teoria cientificista do racismo. O obstáculo epistemológico que Nina Rodrigues teve de enfrentar era da ordem da política estatal, que estava voltada para a preservação do poder da oligarquia rural branca, desgastadá com a guerra do Paraguai, razão pela qual não figurava entre suas prioridades orçamentárias prestar assistência clínica aos escravos e depois aos ex-escravos negros. Ao invés de se opor a isso, Nina Rodrigues tomou o partido da classe senhorial.

Note-se que estamos trabalhando, no plano teórico, com a realidade dinâmica de uma contradição entre elementos de situações sociais e contextos históricos determinados. Os elementos relacionam-se de maneira complexa e se deslocam constantemente de uma perspectiva para outra. Nesse conflito de realidades opostas, em processos de interação recíproca, ganha relevo a negatividade do movimento diante do espaço da positividade empírica. Em conseqüencia, opera-se um choque que transforma a realidade positiva em uma realidade nova. Esta síntese decorre da força crítica da negatividade, que comanda a mudança. Aqui as coisas se movem de maneira tal que, na matéria em questão, um elemento ora é $\mathrm{x}$, ora é $\mathrm{y}$. Ou melhor, a matéria em questão ao mesmo tempo tem jeito de $\mathrm{x}$ e de $\mathrm{y}$. Essa interpenetração mútua dos elementos contraditórios é fruto do caráter múltiplo das perspectivas da situação social e do contexto histórico em que eles ocorrem.

O quadro é outro se se trabalha com a antinomia. Ou seja, na antinomia os elementos opostos são coisas clara e inequivocamente separadas. É preto ou branco. É bem $x$, ou bem $y$, sem nuanças de deslocamentos e interpenetrações. Um se opõe ao outro de maneira excludente. Não se dá a simultaneidade ou reciprocidade de movimentos dos contrários. Aqui o contexto e a situação desaparecem por completo. Nesse caso, as coisas acontecem de maneira unidimensional ou, no máximo, bidimensional, 0 ou 1.

Então a oposição fica congelada com tal rigidez que sua resolução é antecipada, esvazia-se de toda sua negatividade e gera 
a impressão de um voto fraudado, de um conchavo, de um conflito forjado cujo resultado foi cuidadosamente pré-arranjado, de acordo com o modelo da arbitrariedade conciliadora da oligarquia brasileira tradicional, ou do diletantismo dos processos culturais da colônia e do Império. Ali os personagens conservadores de um certo tipo de corporação intelectual atuam sem espírito científico, sem compromisso profissional. Incorrem na trivialidacle positivista, viés que está presente até hoje no pensamento contemporâneo. Por isso, não produzem saber original, a não ser em momentos de crise social, ou como conseqüência da dinamização de elementos endógenos por indução de agentes exógenos. Ou por outra, os processos autônomos são excepcionais. As rupturas são raras. As descontinuidades nem sempre obedecem a decisôes conscientes. Os cortes epistemológicos são fenômenos pouco freqüentes em nossa história das ciências.

Parafraseando Jameson (1997), quero dizer que ele me ajudou a formular melhor o traçado dessa trajetória, movimento das coisas em que é indispensável discernir quem é capaz de saber qual a semente que brotará, e qual a que morrerá, no sulco aberto pelos pioneiros.

\section{Conclusão}

Na história das ciências no Brasil, a medicina ocupa um lugar importante. A prática e o saber médicos remontam aos primórdios de nossa formação social, política e espiritual. Principalmente como prática, a medicina percorreu os mais diferentes estágios de desenvolvimento, que começou com formas rústicas de atendimento ao doente, identificação empírica de remédios oriundos da floresta e aplicação de procedimentos terapêuticos de natureza mágica. Em meados do século XIX, passaram a ter certo relevo formas de atenção, diagnóstico e tratamento aprendidas em universidades européias, especialmente francesas, e de suas correntes especulativas.

A medicina de índole universitária demorou a se enraizar entre nós. Mesmo em nossas escolas superiores isoladas, o conhecimento científico enfrentou muitos obstáculos para ser reconhecido. A defasagem teórica em relação à Europa prolongou-se até a segunda metade do século XIX. Passaram a se difundir em círculos ilustraclos concepções de fundo experimental dos grandes anatomistas, patologistas e fisiologistas franceses e de outras origens, mas encontrando a resistência da elite médica conservadora.

Procurei demonstrar que a primeira iniciativa consistente de ruptura com o modelo tradicional deve ser creditada à Escola Tropicalista Baiana, um grupo particular de médicos estrangeiros - Wücherer, Paterson e Silva Lima - que haviam assimilado muito 
bem os conhecimentos mais atualizados em matéria de fisiologia clínica e anatomia patológica experimental, em circulação principalmente na França, Grã-Bretanha e Alemanha. A escola alcançou êxito ao descobrir, de maneira original, a etiologia de várias doenças típicas de nosso meio. Chama atenção também o interesse que demonstrou pelas afecções dos escravos negros e da população pobre em geral, assim como pelo modelo de medicina preventiva, de preferência à curativa.

O grupo começou a denunciar os primeiros sinais de declínio quando acolheu em seus quadros um médico brasileiro mulato Nina Rodrigues - que se sentiu frustrado em seu propósito de dar continuidade às pesquisas em doenças tropicais. Outro obstáculo foi a falta de espírito de escola, cujo elemento aglutinador estava desaparecendo com a morte ou o afastamento de seus fundadores.

O momento que marca o desaparecimento da razão de ser da escola e sua conseqüente decadência corresponde ao período em que o jovem pesquisador adventício decide alterar bruscamente o rumo de sua trajetória científica. A partir do saber médico erguido nos pilares da anatomia patológica, da parasitologia e da fisiologia clínica experimental, tendo em vista principalmente prevenir e curar as doenças dos negros de origem africana, Nina Rodrigues enveredou pela pesquisa em antropologia criminal e medicina legal, com o objetivo explícito de construir a teoria da inferioridade da população negra e mestiça. Como resultado prático dessa pesquisa, ele esperava aparelhar a classe senhorial branca com os meios de controle jurídico e coerção policial dos grupos raciais, cujas taras congênitas os levavam à criminalidade e à prática de ações que pusessem em perigo a estabilidade do poder político dominante. Suas idéias despertaram a simpatia da elite médica. Algumas delas, porém, por excessivamente disparatadas, não foram incorporadas ao código penal brasileiro, como era de seu desejo.

A Escola Tropicalista Baiana nasceu guiada pela lógica do atendimento às necessidades básicas da parcela majoritária da população nacional. Paulatinamente, sobretudo depois da morte de Wücherer e do ingresso de Nina Rodrigues, suas atividades passaram a se concentrar em assuntos de cunho institucional do aparelho de Estado, diminuindo a liberdade de criação intelectual, ousadia científica e iniciativa operacional. Arrefeceu o entusiasmo pela pesquisa, pois Wücherer e seus parceiros mais próximos não estavam mais comunicando paixão ao que lá se fazia, o que afrouxou a coesão do grupo. Nina Rodrigues dizia francamente que queria fazer ciência sem paixão pela sorte dos negros, numaatitude coerente com a mentalidade cartesiana, para a qual os sentimentos atrapalham a razão clara. Jejuno dos clássicos humanistas, foi-lhe fácil aderir ao utilitarismo positivista. 
A clínica baseada na anatomia patológica experimental nasceu com a abertura de cadáveres por Bichat, que via na morte um fenômeno positivo porque oferecia a chave explicativa do funcionamento da vida, condição de produção do discurso científico nos seus aspectos orgânico e simbólico. Nina Rodrigues escolheu também abrir cadáveres, nos quais ele lia os sinais de degeneração de seus irmãos de cor. A morte deles, portanto, não foi condição de produção de um novo discurso científico que tornasse seu autor sensivel para mergulhar nas entranhas ocultas da vida dos escravos negros. A antropologia criminal, abençoada por Lombroso e por todos os racistas brasileiros, serviu para que uma escuridão macabra se abatesse sobre aquela raça de párias, para os quais o crepúsculo da mestiçagem nem sempre seria um atenuante para o estigma da servidão.

De seu lado, o 'sol negro', envergando a couraça fria da razão cientificista, colocou o exercício da medicina legal a serviço da institucionalização oficial da Escola Tropicalista Baiana. Esta passou a se concentrar em temas de interesse do poder estatal, embotando sua veia crítica, abandonando o diapasão dos conflitos entre as necessidades sociais e a razão de Estado, levando ao paroxismo o discurso da antinomia, sintoma da contradição. Este foi o caminho de sua decadência. As formas ocultas da realidade profunda projetavam-se sobre a superfície visivel, assumindo a aparência da "planitude anamórfica de uma imagem remanescente praticamente irreconhecível, vindo à luz na forma de um paradoxo lógico ou de um paralogismo textual" (Jameson, 1997, p. 20). O projeto da pesquisa soturna de Nina Rodrigues degradou-se no protocolo de uma aberração. E seu resultado foi a representação do negro condenado à morte civil. O trabalho do anatomista taciturno, a contrapelo da lição de Bichat, não tinha a função escrutinadora de abrir o olhar para decifrar o segredo da libertação do corpo do doente. Pelo contrário, a medicina legal fora criada para conferir legitimidade científica à autópsia que atestava a inferioridade do paciente. Era uma ciência aporética, parecida com a de Jobim: trocava o efeito pela causa. Congelava a antinomia. Ora, a anemia não era causa da ancilostomíase, mas efeito da ação do helminto, parasito intestinal que consumia o sangue do enfermo. De igual modo, é uma inversão cognitiva asseverar que o escravo era causa de desordem, doenças e brutalidades, ou foco de "doenças próprias de suas disposições hereditárias", ou raça inferior que promovia o atraso social. Na verdade, era a estrutura senhorial que bloqueava o progresso social e fazia do escravo um homem espoliado e doente. A anemia era sintoma da parasitose como a anomia social era sintoma da dominação escravocrata. Como a antinomia é sintoma da contradição. 
Enquanto lidavam com a contradição, Wücherer e seus pares fizeram uma ciência de descobertas originais, em benefício dos escravos negros. Ao substituir a contradição pela antinomia, Nina Rodrigues provocou a artrose do pensamento criador, abafou as condições de possibilidade de descobertas, e fez ciência predicativa, disciplinar e hierárquica, em detrimento dos negros e mestiços. Visando a morte da liberdade de seus iguais, Nina Rodrigues voltava a arma da morte contra seu próprio ser, sufocado por impasses sociais, intelectuais, políticos, éticos e afetivos que ele nunca foi capaz de superar. Talvez aí esteja a chave de sua morte prematura, em Paris, sem choro nem vela, longe dos terreiros iorubas onde exerceu o ofício precursor de primeiro antropólogo dos afro-brasileiros (Coni, 1952, p. 73).

\section{REFERENCIAS BIBLIOGRÁFICAS}

Americano, Domingos

Marinho Azevedo 1846

Andahazi, Federico 1997

Azevedo, Fernando de (org.)

1994

Bachelard, Gaston 1977

Bachelard, Gaston 1967

Bachelard, Gaston 1934

Baiardi, Amilcar 1996

Barros, Pedro Motta de 1997

Barros, Roque Spencer Maciel de 1986

Benchimol, Jaime Larry, e Teixeira, Luiz Antonio 1993
Memória sobre o estado atual das instituiçōes médicas em França, na Prússia e na Grã-Bretanba, Tipografia Nacional, Rio de Janeiro. Apud Edler, 1992, 43, passim. Esta fonte, p. 277, fixa a data de publicação em 1845. Segundo Santos Filho, II, 1991, 130, o relatório de Americano foi publicado em 1844.

O anatomista. Trad. Paulina Wacht e Ari Roitman, Rio de Janeiro, Relume-Dumará.

As ciências no Brasil.

Rio de Janeiro, Editora UFRJ, 2 vols.

O racionalismo aplicado.

Trad. Nathanael C. Caixeiro, Rio de Janeiro, Zahar.

La formation de l'esprit scientifique: contribution à une psychanalyse de la connaissance objetive. $5^{\text {n }}$ ed., Paris, J. Vrin.

O novo espirito científico.

Lisboa, Edições 70.

Sociedade e estado no apoio à ciência e à tecnologia: uma análise bistórica. São Paulo, Hucitec.

Metamorfoses da modernidade: consideraçōes sobre as raízes da modernizaçâo no Brasil. Tese de doutoramento, São Paulo, Faculdade de Filosofia, Letras e Ciências Humanas da Universidade de São Paulo.

A ilustraçâo brasileira e a idéia de universidade.

São Paulo, Convívio/Edusp.

Cobras, lagartos \& outros bichos. Uma bistória comparada dos institutos Oswaldo Cruze Butantan.

Rio de Janeiro, Editora UFRJ. 


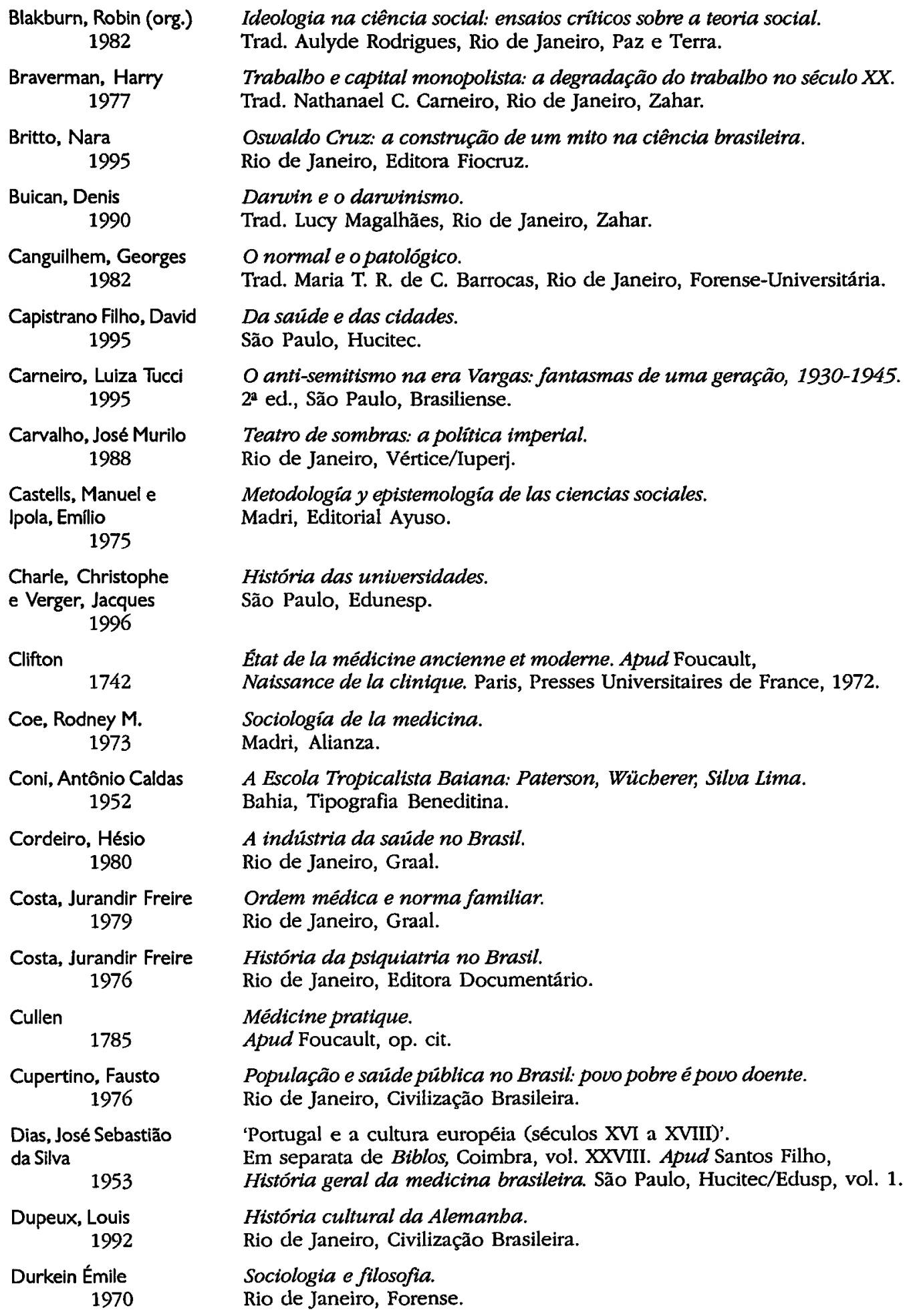


Edler, Flávio Coelho 1992

Faoro, Raymundo 1974

Febvre, Lucien 1968

Ferreira, Oliveiros S. 1986

Figueiredo, C. A. Moncorvo de 1874

Figueirôa, Silvia Fernanda de Mendonça 1992 Foucault, Michel
1972

Franco, Francisco de Melo 1994

Franco, Afonso

Arinos de Melo

1976

Frielro, Eduardo 1981

Frier

1789

Geymonat, Ludovico 1985

Glibert, 1772

Gledson, John 1991

Goldhagen, Daniel Jonah 1997

Gorz, André

1964

Gramsci, Antonio 1991

Gramsci, Antonio 1968

Guindant, T. 1768

Houaiss, Antonio (org.) 1979
As reformas do ensino médico e a profissionalização da medicina na corte do Rio de Janeiro, 1854-1884. Tese de mestrado, São Paulo, Faculdade de Filosofia, Ciências e Letras da Universidade de São Paulo.

Machado de Assis: a pirâmide e o trapézio.

São Paulo, Companhia Editora Nacional.

Le probléme de l'incroyance au $X V V^{*}$ siècle: la religion de Rabelais. Paris, Albin Michel.

Os quarenta e cinco cavaleiros búngaros: uma leitura

dos Cadernos de Antonio Gramsci.

São Paulo/Brasília, Hucitec/Edunb.

Do exercício e ensino médico no Brasil. Apud Edler, op. cit.

Ciência na busca do Eldorado: a institucionalização das ciências geológicas no Brasil, 1808-1907. Tese de doutoramento, São Paulo Departamento de História da Faculdade de Filosofia, Letras e Ciências Humanas da Universidade de São Paulo.

Naissance de la clinique.

Paris, Presses Universitaires de France.

Medicina teológica (1794).

São Paulo, Editora Giordano.

Um estadista da Repuiblica.

Rio de Janeiro, Nova Aguilar.

O diabo na livraria do cônego.

$2^{\underline{1}}$ ed., Belo Horizonte/São Paulo, Itatiaia/Edusp.

Guide pour la conservation de l'bomme.

Apud Foucault, op. cit.

Historia de la filosofia y de la ciencia.

Barcelona, Grijalbo/Crítica.

L'anarcbie médicinale. Apud Foucault, op. cit.

Macbado de Assis: impostura e realismo - uma reinterpretaçâo de Dom Casmurro. São Paulo, Companhia das Letras.

Os carrascos voluntários de Hitler: o povo alemão e o bolocausto. São Paulo, Companhia das Letras.

Historia y enajenación.

México, Fondo de Cultura Económica.

Maquiavel, a política e o estado modemo. $8^{\underline{a}}$ ed., São Paulo, Civilização Brasileira.

Os intelectuais e a organizaçâo da cultura.

Trad. Nelson Coutinho, Rio de Janeiro, Civilização Brasileira.

La nature opprimée par la médicine moderne. Apud Foucault, op. cit.

Enciclopédia Mirador Internacional.

São Paulo/Rio de Janeiro, Encyclopaedia Britannica do Brasil. 


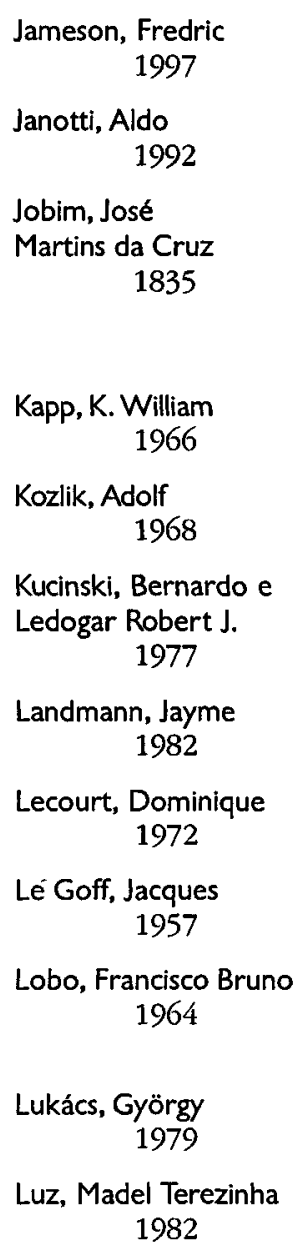
Machado, Roberto, et alii
1978

Macpherson, C. P. 1970

Marx, Karl e Engels, F. 1971

Maxwell, Kenneth 1996

Mello, Carlos Gentile de 1981

Monteiro, João Paulo 1975

Monzani, Luiz Roberto 1995
As sementes do tempo.

São Paulo, Ática.

Origens da universidade: a singularidade do caso português.

$2^{a}$ ed., São Paulo, Edusp.

'Discurso sobre as moléstias que mais afligem a classe pobre do Rio de Janeiro'. Apud Wücherer, 1866, I (3): 29. Segundo Luz (1982, pp. 126 e 129), o trabalho de Jobim foi publicado em Revista Médica Brasileira,

Rio de Janeiro, 1 (7), nov. 1841: 351-359. Para Santos Filho (1992, p. 271), a publicação está em Revista Médica Fluminense, Rio de Janeiro.

Los costes sociales de la empresa privada.

Barcelona, Ediciones Oikos-Tau.

El capitalismo del desperdicio: el milagro económico norteamericano.

México, Siglo Veintiuno.

Fome de lucros: atuaçâo das multinacionais de

alimentos e de remédios na América Latina.

Trad. Jurandir Craveiro, São Paulo, Brasiliense.

Evitando a saúde E promovendo a doença.

$2^{\mathrm{a}}$ ed., Rio de Janeiro, Achiamé.

Pour une critique de l'épistémologie (Bachelard, Canguilbem, Foucault).

Paris, François Maspéro.

Les intelectuels au Moyen Âge.

Paris, Éditions du Seuil.

O ensino da medicina no Rio de Janeiro: 1964-1969. Apud Pires,

Hegemonia médica na saúde e a enfermagem no Brasil: 1500 a 1930.

São Paulo, Cortez, 1989.

Ontologia do ser social: os principios ontológicos fundamentais de Marx.

Trad. Carlos Nelson Coutinho, São Paulo, Ciências Humanas.

Medicina e ordem política brasileira: politica

e instituições de saúde (1850-1930).

Rio de Janeiro, Graal.

Danação da norma: a medicina sociale

a constituição da psiquiatria no Brasil.

Rio de Janeiro, Graal

La teoría politica del individualismo posesivo: de Hobbes a Locke.

Barcelona, Editorial Fontanella.

Epistolario. Recopilación y selección de cartas de los autores,

tomadas de la versión española de las Obras escogidas de C. Marx y F. Engels, Moscou, 1969, y de la Correspondencia, editada por el Instituto Marx-EngelsLenin de Leningrado, 1934. México, Editorial Grijalbo.

Marquês de Pombal: paradoxo do Iluminismo.

Trad. Antônio de Pádua Danesi, Rio de Janeiro, Paz e Terra.

O sistema de saúde em crise.

São Paulo, Cebes/Hucitec.

Teoria, retórica, ideologia.

São Paulo, Ática.

Desejo e prazer na idade moderna.

Campinas, Editora da Unicamp. 


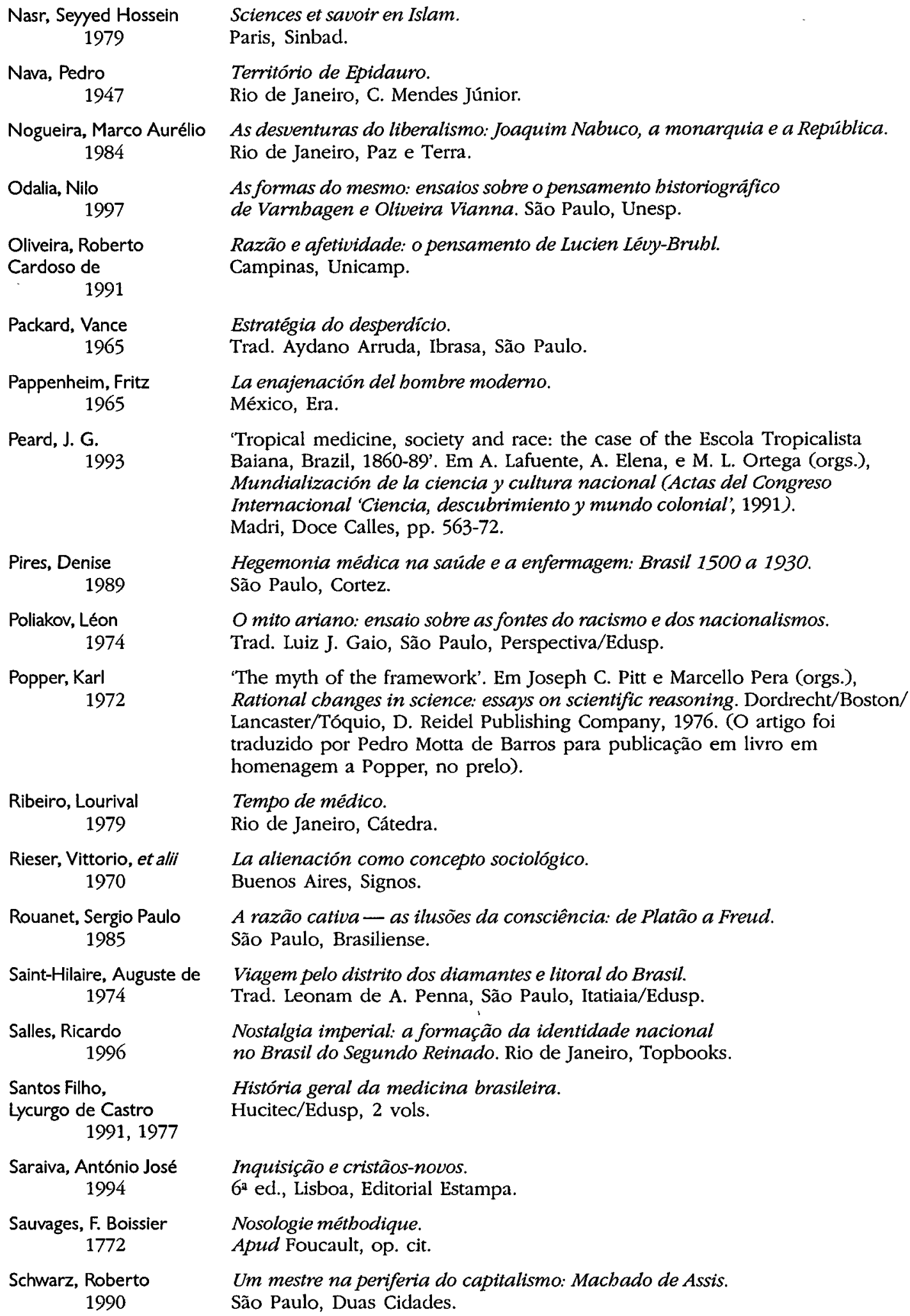


Schwarz, Roberto 1977

Sebrell, William Henry, e Harris, Robert S.

(org.) 1954

Sevcenko, Nicolau 1994

Sevcenko, Nicolau 1985

Simmel, Georg 1993

Skidmore, Thomas $\mathrm{E}$. 1989

Starobinski, Jean 1967

Sydenham, Th. 1784

Testa, Mario 1995

Thiery 1789

Tsuru, Shigeto (org.) 1964

Uricoechea, Fernando 1978

Varnhagen, Francisco

Adolfo de s. d.

Villarreal, René 1984

Wücherer, Otto

Edward Henry 1866
Ao vencedor as batatas.

São Paulo, Duas Cidades.

Vitamins: chemistry, plyysiology, patbology.

Apud Houaiss,op. cit.

O Renascimento

$18^{\mathbf{a}}$ ed., São Paulo, Atual Editora.

Literatura como missão: tensões sociais e criação cultural na Primeira Repiüblica. $2^{\mathfrak{a}}$ ed., São Paulo, Brasiliense.

Filosofia do amor.

São Paulo, Martins Fontes.

Preto no branco: raça e nacionalidade no pensamento brasileiro. Trad. Raul de Sá Barbosa, $2^{a}$ ed., Rio de Janeiro, Paz e Terra.

História da medicina.

Trad. Jaime da Cruz, Lisboa, Livraria Morais Editora.

Médicine pratique.

Apud Foucault, op. cit.

Pensamento estratégico e lógica de programação: o caso da satide. Trad. Angela M. Tijiwa, São Paulo, Huitec/Abrasco.

Voeux d'un patriote sur la médicine en France.

Apud Foucault, op. cit.

¿Adónde va el capitalismo?.

Barcelona, Ediciones de Occidente.

O minotauro imperial: a burocratização do estado patrimonial brasileiro no século XIX.

São Paulo, Difel.

História geral do Brasil.

$4^{a}$ ed., Rio de Janeiro, J. E. \& Laemmert Ltd., 5 vols. Apud Odalia.

A contra-revoluçâo monetarista: teoria, política

econômica e ideologia do neoliberalismo.

Trad. Ruy Jungmann, Rio de Janeiro, Record.

'Sobre a moléstia vulgarmente denominada opilação ou cansaço'. Em Gazeta Médica da Babia, I (3), 10/8: 27-9; (4), 25/8: 39-41; (5), 10/9: 52-4; (6), 25/9: 63-4, Salvador, Typographia de Tourinho. Edição fac-similar, Escola Paulista de Medicina, Brasiliensia Documenta, vol. IX, t. I, Revista dos Tribunais, São Paulo, 1974. 